University of Nebraska - Lincoln

DigitalCommons@University of Nebraska - Lincoln

1999

Control of the Air: The Enduring Requirement

Richard P. Hallion

SES

Follow this and additional works at: https://digitalcommons.unl.edu/usafresearch

Part of the Aerospace Engineering Commons

Hallion, Richard P., "Control of the Air: The Enduring Requirement" (1999). U.S. Air Force Research. 5.

https://digitalcommons.unl.edu/usafresearch/5

This Article is brought to you for free and open access by the U.S. Department of Defense at DigitalCommons@University of Nebraska - Lincoln. It has been accepted for inclusion in U.S. Air Force Research by an authorized administrator of DigitalCommons@University of Nebraska - Lincoln. 


\section{CONTROL OF THE AIR: THE ENDURING REQUIREMENT}

By

Dr. Richard P. Hallion, SES

Air Force History and Museums Program

Bolling AFB, DC 20332-1111

September 8, 1999 


\section{Contents}

I. Control of the Air, The Three Freedoms, and the

Spectrum of Air Warfare $\quad 4$

II. Air Superiority: The Danger of Illusory Dominance 8

III. Air Supremacy: Dominant Air Warfare

With Decisive Results 22

IV. How Control of the Air Can Be--and

Sometimes Has Been--Lost $\quad 50$

V. Implications for the Future of American Air Supremacy 64

$\begin{array}{lr}\text { Source Notes } & 68\end{array}$ 
I.

\section{Control of the Air, the Three Freedoms, and the Spectrum of Air Warfare}

Throughout the military history of the twentieth century, the role of aerospace forces has become more predominant. Today, wars typically start, are prosecuted, and reach their decisive culminating point--whether surrender of a foe, agreement to a ceasefire, or the ceasing of combat operations--thanks to air action. Given these circumstances, to lose control of the air is to lose a war, particularly in an era (as we now are in since the end of the Cold War) when deployable overseas forces are small, and, thus, particularly vulnerable to the tremendous leverage an opponent gains by sudden and swift air attack. If fighting under near "parity" conditions, the battle for control of the air takes on even more critical importance: a nation fighting an equivalent, or nearequivalent, forces finds that in the absence of clear control of the air, all of its other military operations are constrained:

Fighting under these conditions, air power forces have to first ensure their own survival before fulfilling whatever mission objectives they are trying to achieve. For example, ground attack operations are hindered, as these kinds of aircraft are vulnerable to enemy fighters. Air mobility is restricted both in-theater and, perhaps, en-route to the theater, as enemy fighters attack essentially defenseless transports. Command-andcontrol aircraft, typically using transport airframes, likewise are rendered vulnerable to marauding enemy air forces. Air superiority forces are forced to fight both defensively as well as offensively, constraining their ability to dominate the enemy over that foe's territory. 
But the dangers of parity air war do not just affect air operations. Operations of all other military forces are constrained as well. For armies, operations across an entire Corps may be affected by even sporadic enemy air attacks. The "fog and friction" issues increase, eroding confidence among forces, and promoting the danger of fratricide, as harassed ground forces begin to view any aircraft as an enemy. Defense become dominant, maneuver is hindered, and casualties increase as combat operations take longer to conduct, and with less effectiveness. For navies, an enemy that can strike at the heart of a fleet can inflict horrendous losses to shipping via bombs and guided missiles. Again, a defensive mindset begins to predominate. Further, since damaged or sunken ships carry a large "price-tag" of national prestige and, even worse, lives, the loss or damage of even a single major vessel can have a shattering impact upon public opinion and resolve.

The importance of securing and maintaining control within a theater of operations is so critical to military operations that its need is self-evident. Nevertheless, it is worthwhile to consider its implications, and the conditions and states of air warfare. Broadly speaking, control of the air enables a nation to prosecute the fullest range of offensive operations by all its forces against a foe, while, at the same time, insulating those forces defensively from meaningful enemy counterattacks. Coming from this are some obvious advantages, particularly what might be termed the "three freedoms": the freedom of initiative, the freedom to operate, and the freedom to maneuver. Freedom of initiative refers to the ability of the air-dominant adversary to control the tempo, strategic and tactical thrust, and nature of the conflict: to hold an adversary in a defensive, reactive, behind-the-decision-making-curve. Freedom to operate is characterized by the ability of military forces to conduct all of their functions, particularly that of attacking a foe, 
without fear of that foe attacking them in any meaningful or significant way in return: in short, freedom to attack while enjoying freedom from attack. Freedom to maneuver embraces the ability for joint military forces to operate unhindered on land and sea within an area of operations, and in the air and below the sea as well, including both direct combat operations (such as troop movements or bomber sorties) and any supporting ones as well (such as air mobility operations, or movement of resupply vessels).

As there is a general spectrum of warfare, there is, as well, a spectrum of air warfare. The five conditions reflecting this spectrum are air paralysis, air inferiority, air parity, air superiority, and air supremacy. Air paralysis typifies a nation unable to undertake offensive military action of any significance because it is controlled by enemy air forces; there is no hope of victory, and the enemy has air supremacy. Air inferiority implies that a nation can undertake limited offensive military action possessing some potential significance, but only by taking the enemy's air activity into consideration. Further, the enemy's air superiority forces the emphasis of most operations to switch from offensive to defensive warfare. Thus, there is little hope of victory. Air parity suggests that both sides are so relatively balanced in forces, capabilities, training, etc. that each can secure, by marshaling the necessary forces at a particular time and point, localized air superiority over a portion of a front or theater. Indeed, even at the same time, different portions of the front or theater may be controlled by different sides. But neither side can possess superiority over the entire front or theater, and either side may secure victory if their particular fortunes or circumstances change. Air superiority characterizes a war where a nation that can exert its power over a foe with few air losses of its own, and without serious concern about the enemy's ability to contest for control of the air with its 
own air forces. The foe, suffering from air inferiority, can only undertake limited offensive action, and must devote the bulk of activity to defensive warfare. There is, as a consequence, a high expectation of victory, though that victory may still take some time and entail further losses. Air supremacy implies that a nation can control a foe with essentially no or absolutely minimal air losses of its own, and without need to concern itself about the enemy's air intentions. The enemy cannot undertake any offensive operations, and few, if any, defensive ones. If these conditions exist across an entire theater, then victory is essentially assured aside from Deus ex machina third-party interventions. The foe, needless to say, is in a state of air paralysis.

It should be noted that these five conditions comprising the spectrum of air warfare reflect three basic "states of nature" of air warfare as well: Air Subordination (paralysis and inferiority), Air Parity, and Air Domination (superiority and supremacy). Finally, the battle for control of the air is commonly thought of as involving defeating the air-to-air threat: the enemy fighter. But, particularly in recent years, defeating the surface-to-air threat--especially in the surface-to-air (SAM) missile age--has taken on its own grave importance. And the continuous upgrading and internetting of both air and surface air control forces--fighters, SAMs, antiaircraft artillery (AAA), radars, and command and control elements--makes this a profound challenge, and one that itself forces a serious examination into the nature of future forces and how they are employed. 
II.

\section{Air Superiority: The Danger of Illusory Dominance}

Clearly, no nation would willingly pursue an acquisition strategy that would guarantee that its combat forces should fight at conditions of air subordination or air parity. Warfare is not like an athletic contest, where one desires the excitement of the close match; rather, since the days of Sun Tzu, it has been recognized that a nation should use military force swiftly, decisively, and overwhelmingly, with the greatest possible degree of thorough planning, demanding training, excellent equipment, and knowledge of the enemy. Therefore, the question is really one of pursuing a strategy that seeks lesser (superiority) or greater (supremacy) air dominance over one's opponent. Here, the lessons of history and various historical examples can be profoundly instructive.

First, overall, combat experience indicates that a nation possessing mere "air superiority" experiences far more limitations than advantages, and assumes far greater-and occasionally fatal--risks. Some examples clearly point to this.

\section{Springtime for Hitler: The Luftwaffe's Blitzkrieg to Defeat. . .}

During the "blitzkrieg" of 1939-1940, the German Luftwaffe rapidly overwhelmed its adversaries. Even so, the degree of superiority of Nazi aircraft over their opponents was not so great as to preclude operations by the enemy air forces that inflicted serious losses. The invasion of Poland cost the Luftwaffe 285 aircraft, 18\% of the operational strength committed to the campaign. Norway and Denmark cost a further 242 airplanes, mostly transports. Fully $21 \%$ of the Luftwaffe's combat aircraft committed to the Battle of France were destroyed on operations from enemy action: 1,129 out of 5,349 aircraft. In 
sum, despite having secured air superiority over the European continent, the Luftwaffe-bruised in Poland, bloodied in Norway and Denmark, and wounded in France--was but weeks away from being beaten by the Royal Air Force in the epochal Battle of Britain.

"Their Finest Hour" or, Minimally Winning the Right to Continue the Fight. . .

Indeed, during the Battle of Britain, the Royal Air Force had a greater than 2: 1 victory-loss ratio over Hitler's Luftwaffe. It was sufficient to win the battle and preserve Great Britain for use as a base for the combined RAF-US Army Air Forces strategic bomber offensive that set the stage for the invasion of Europe in 1944. For the first time in history, a nation was saved from imminent disaster through the use of decisive air power. But as significant as the victory was, the margin of superiority that the RAF possessed over the Luftwaffe was not so great as to result in the RAF utterly dominating the Luftwaffe and forcing an early termination to the war. In fact, in 1941, the RAF experienced similar loss rates to that of the Luftwaffe when it began to operate over the Channel against German targets in France, so that the war was still, very much, a "close run thing."

\section{Midway: “Incredible Victory,” but not Victory Enough. . .}

At the Battle of Midway in 1942, the Japanese, through a combination of previous victories, better aircraft technology, and larger forces, possessed air superiority over defending American forces. They showed that air superiority early in the battle both during a raid on Midway Island and then in defending their carriers against attacking American torpedo bombers. But that air superiority was nevertheless insufficient to prevent a small force of American dive-bombers to approach undetected until after the point of weapon release, dooming three carriers and giving air superiority to the United 
States. And then that level of American air superiority was insufficient to prevent the remaining fourth Japanese carrier from launching an air strike (just before it was sunk) damaging one American aircraft carrier so badly that it was easy prey for a submarine.

\section{The 'Canal: Air Parity Produces an Aerial Verdun. . .}

At the critical battle of Guadalcanal, a six-month struggle from August 1942 through early February 1943, control of the air was critically important. Indeed, historian Richard Frank has concluded that "Without a doubt, the air struggle produced the most important long-term military effect of the Guadalcanal campaign."1 This bitter battle offers a significant lesson on the dangers of operating under essentially "air parity" conditions. Overall, based on examination of postwar records and looking just at combat losses, the United States enjoyed a 1.69 : 1 victory-loss ratio over the Japanese: Japan lost 446 fighters, bombers, and torpedo planes, and America 264 of its own. But even though this technically gave American airmen "air superiority," in reality prospects of victory see-sawed for months between the Americans and the Japanese, largely because the United States lacked clear and overwhelming air supremacy that would have greatly eased both air and surface operations.

In fact, a closer examination of fighter-vs.-fighter losses shows that, over the most critical time period of the campaign (from August 1, 1942 through November 15, 1942), 115 Japanese fighters were lost in air combat, as compared to 114 American ones, virtually a $1: 1$ exchange ratio. Indeed, if one examines just losses of Japanese and American fighters over the length of the entire campaign (August 1, 1942-February 9, 1943) from all causes, both combat and operational, 290 American and 261 (possibly 262) Japanese fighters were lost: a ratio of $1.11: 1$ in favor of Japan. It is fortunate that 
American airmen accomplished what they did against Japanese attack forces given these results. American and Japanese airmen fought under conditions of, essentially, "fighter parity," suggesting that two disadvantages under which the Japanese flew played the decisive role.

First, Japanese air operations took place over long distances that limited combat time and, worse, doomed damaged aircraft to be lost (usually with their crews as well). In contrast, Americans (like the RAF in the Battle of Britain) were flying in generally close proximity to their own base at Henderson Field and a nearby fighter strip. Second, though slower and less agile than their Japanese opponents, American fighters typically had heavy armor for crew, engine, and fuel system protection and four or six fast-firing long-range $12.7 \mathrm{~mm}$ (.50 caliber) heavy machine guns that could do serious damage to any opponent. In contrast, Japanese aircraft designers typically emphasized performance over armor protection for crews and fuel systems, so that if even they were damaged and survived the immediate encounter, under the circumstances of Guadalcanal fighting, they often crashed or ditched on their way home. Exacerbating this was the relatively light and short-range armament of Japanese Mitsubishi A6M “Zero" fighters--two $20 \mathrm{~mm}$ cannon and two $7.7 \mathrm{~mm}$ machine guns--that lacked the quick, devastating punch of the American $12.7 \mathrm{~mm}$ machine gun. While an American pilot could score quickly (and at great range) against a Japanese aircraft that passed even briefly through his bullet stream, the same was not true for a Japanese pilot given a more rugged American airplane in his gun sight.

Given these conditions, had either side possessed a better air-dominant fighter having a higher probability of kill per engagement, the outcome of the battle might have 
been dramatically different. Protected from Japanese fighter attack, American airmen could have won a quicker, less costly victory, and many of the ships lost from enemy air attack or from enemy surface action (because of the protracted nature of the campaign) might have been saved. Protected from American fighter attack, Japanese airmen might have destroyed American air forces, sunk the Navy's remaining carriers, forced a withdrawal (or even a humiliating surrender) of the invasion forces, and secured the kind of strategic advantage that had eluded them previously at Coral Sea and Midway. American fighter pilots had to be as concerned about protecting themselves as in destroying the enemy. Under these circumstances, it is not surprising that, with but marginal air superiority and the clear lack of genuine air supremacy, this pivotal campaign took both as long as it did, and the air battle around Guadalcanal, again in the words of Richard Frank, "took the aspect of a large-scale attritional battle where the outcome is gauged principally in overall crew and aircraft casualties." ${ }^{2}$ Despite illusory American "air superiority," Guadalcanal was, in reality, an aerial Verdun.

\section{Kasserine: The Price of Flawed Doctrine. .}

In early 1943, over the Western Desert, the Royal Air Force and U.S. Army Air Forces clearly possessed air superiority over the Luftwaffe. Yet that superiority was insufficient to prevent the Luftwaffe from savaging American ground forces at the battle of Kasserine in a series of strikes that forever sensitized the U.S. Army to the power of enemy air attacks. The experience was so shocking that it resulted in a fundamental reexamination of American air doctrine, which had overemphasized tying aircraft too closely to the needs of the Corps commander as opposed to the advantage of operating them more broadly. Kasserine directly led to the issuance of what has been called the 
"Declaration of Independence" of the U.S. Air Force, War Department Field Manual FM 100-20. FM 100-20, not surprisingly, stated that the first and most important mission for air power forces was securing control of the air. "Without this air supremacy," the manual stated, "the initiative passes to the enemy.",3

“Air Superiority” Confronts the Kamikaze--and not Very Well At That. . .

In 1944-45, American naval aviation forces had undoubted air superiority over their Japanese foes. Yet, as great as that superiority was, it was insufficient to prevent approximately 2,800 Kamikaze attackers breaking through defenses, sinking 34 Navy ships, damaging 368 others, killing 4,900 sailors, and wounding over 4,800 more. Despite radar detection and cuing, airborne interception and attrition, and massive antiaircraft barrages (some of which shot down defending Navy fighters), 14 percent of Kamikazes survived to score a hit on a ship, and nearly 8.5 percent of all ships hit by Kamikazes sank. Protecting its ships from air--and subsequently missile--attack constituted one of the U.S. Navy's major thrusts in the postwar era, as its development of ever more sophisticated radars, fighters, surface-to-air and air-to-air missiles, and gun systems indicated.

Introduction of the German Jets: High Technology as Force-Multiplier. . .

At that same time, 1944-1945, the Royal Air Force and the U.S. Army Air Forces had clear air superiority over the heartland of the Third Reich. Yet, even so, when the Germans introduced the first jet fighters into combat, the overwhelming air superiority of the Allies' conventional propeller-driven piston-engine fighter forces was insufficient to prevent serious losses of bombers and other "legacy" aircraft due to the newer jets. While the jets themselves shot down only approximately 150 American and British airplanes 
before the collapse of the Third Reich, the disproportionate effort that had to be put into place to prevent their further depredations--for example, special fighter patrols to seek out German jets returning to their home airfields when they were slow, low on fuel, and close to the ground--enabled more of Germany's conventional propeller-driven fighters to survive and score even more greatly against American bombers and other aircraft. Further, the jet threat caused consternation and distraction at the highest levels of the Allied leadership and led to the immediate redirection of the strategic bomber offensive away from support of the Allied armies fighting into the Nazi heartland, and back to strikes against German aircraft production plants. Had Germany introduced jets earlier into combat--in, say, early 1943 as opposed to late 1944--there would have been the very real possibility that the strategic air offensive would have had to be delayed--and hence the invasion of Europe as well--until equivalent Allied jet fighters entered service.

The Air War Over Vietnam: A Confluence of Problems. . .

Vietnam's decade-long air war was, in reality, many air wars: there was the constant air support war in South Vietnam. There was also an air war over Laos and Cambodia, involving reconnaissance and interdiction strikes against the Ho Chi Minh trail, as well as support of special operations forces. Over the North was a war of selective application of air power, largely ineffectual until dramatic changes in leadership and rules of engagement, coupled with changes in tactics, training and the introduction of new technology, led to equally dramatic changes in effectiveness typified by the Linebacker air campaigns of 1972.

In the post-Korean era, the rapid development of air-to-air missiles and the pervasiveness of nuclear thinking led to near-disaster ten years later in the skies over 
Thud Ridge, the Red River, and Hanoi. Prevailing doctrine held that the likelihood of large-scale dogfights between opposing aircraft was declining in the "missile age." As a result, the United States de-emphasized training fighter pilots in classic air combat maneuvering, tactics, and aerial gunnery. Surface-to-air missile threats to air supremacy were largely ignored, so that, in the summer of 1965, Air Force and Navy fighters went into a suddenly SAM-intensive war without even rudimentary electronic warfare protective systems. Overemphasis on beyond-visual-range missile shots against benign targets resulted in fighter squadrons where only a small minority of pilots had ever shot at an aerial target or engaged in hard-maneuvering against other fighters. The fighters themselves suffered from a variety of design deficiencies, and generally were too heavy, too maneuver-restricted, and lacked suitable weaponry and visibility. As a result of hardearned combat experience, such shortfalls were redressed, but it was not until the 1970's that tactics, training, and overall air war strategy came together to generate the successes of 1972 that capped the air war experience of the United States in Southeast Asia.

Fixated on atomic warfare throughout the 1950's, the United States developed "fighters" that were intended, in reality, as either nuclear attack aircraft or interceptors of Soviet long-range bombers. Not one of the Air Force's famed "Century series" fighters (the North American F-100 Super Sabre, McDonnell F-101 Voodoo, Convair F-102 Delta Dagger, Lockheed F-104 Starfighter, Republic F-105 Thunderchief, Convair F-106 Delta Dart, or General Dynamics F-111) was a true air superiority airplane in the tradition of the P-51 of the Second World War or the F-86 of Korea. The same was largely true for the Navy and Marine Corps as well: only one--the Vought F8U Crusader--of the U.S. Navy and Marine Corps' post-Korea fighters (the Grumman F9F Cougar, Grumman F11F 
Tiger, McDonnell F2H Banshee, North American FJ-4 Fury, McDonnell F3H Demon, Douglas F4D Skyray, and Vought F7U Cutlass) was an air superiority fighter in the tradition of the Grumman F6F Hellcat of the Second World War. Even the best American fighter, the joint-service and powerful McDonnell F-4 Phantom II, first flown in 1958, was intended initially as an attack aircraft and only later developed as a longrange point-defense missile-armed interceptor. Vietnam called upon it to be a hardmaneuvering dogfighter instead. So dominant was thinking that the nature of air warfare had irrevocably changed that the Phantom was deliberately designed without provision for an internal gun--a weakness not remedied until desperate air combat in the skies over North Vietnam against cannon-and-missile-armed adversaries had indicated just how necessary one was.

Overall, during the air war over North Vietnam, the United States had a $2.63: 1$ victory-loss ratio comparing all U.S. losses to Vietnamese losses, and, when non-fighter aircraft are removed from the comparison, this rose to a 2.85: 1 air superiority edge over the North Vietnamese Air Force in fighter vs. fighter combat. But even given better radar and missile technology, the primary U.S. air-to-air fighter, the joint service and multipurpose McDonnell-Douglas F-4 Phantom II, had only a 3.46 : 1 overall exchange rate against various (and more agile) MiG opponents. This reflected primarily training, restrictive rules of engagement, and usage deficiencies, but also the problems of operating a heavy airplane never really intended for hard-maneuvering dogfighting against opponents optimized for the air-to-air combat arena. (In Korea, by comparison, F-86 Sabre pilots shot down ten MiG-15's for every Sabre lost, and sometimes as many as fourteen per friendly lost). When Vietnam's numbers are looked at in even greater detail, 
far more serious lessons are drawn: while 1960's Mach 1.5-Mach 2 supersonic American fighters had a 5.70 : 1 advantage over the subsonic Korean War-vintage MiG-17, they only had a $3.33: 1$ advantage over the Mach 1.5 supersonic MiG-19, and but a $1.8: 1$ advantage over the Mach 2 MiG-21.

Under these circumstances, even the presence of a few MiGs threatening airborne strike packages induced a defensive mindset that resulted in strikers jettisoning bombs. As historian Wayne Thompson has written, "Although only a little more than ten percent of the USAF's 625 aircraft losses in combat over North Vietnam were to MiGs, the MiG's caused expensive jettisoning of bombs and the dedication of fighters to patrol duty rather than strike duty."4 For example, by the end of 1967, there were only thirty MiG's operating in North Vietnam--but the percentage of Air Force strike sorties jettisoning bombs rose from $2 \%$ to more than $10 \%$; on December 19 of that year, fully fifty percent of the strikers on one mission--20 of 40 aircraft--jettisoned their bombs when confronted by twelve threatening MiG's. As a result, by February 1968, the ratio of Air Force fighter sweep and fighter escort sorties to strike sorties rose from less than $1: 5$ to $2: 1$. In short, a numerically inferior force of enemy fighters had disrupted an entire campaign, even though that campaign, at least in theory, possessed "air superiority."

Vietnam influenced future American air power in many ways after 1972. Above all else, the services learned first-hand the great risks to control of the air posed by internetted SAM's, fighters, and antiaircraft artillery. As a result, after Vietnam, the United States built on its Vietnam experience by devoting increasing emphasis to electronic warfare and SAM-killing, but especially to the development of new and far better fighter aircraft, the so-called "superfighters" of the 1970's: the Grumman F-14 
Tomcat, McDonnell-Douglas F-15 Eagle, General Dynamics F-16 Fighting Falcon, and McDonnell-Douglas F/A-18 Hornet. Additionally, overall, the experience of Vietnam and the 1973 Arab-Israeli War likewise was the single strongest factor in encouraging the design development of low observable "stealth" aircraft, intended to achieve air supremacy in the face of intensive defenses by confounding the very underlying principles of radar-based antiaircraft defenses.

The Yom Kippur War: Destruction of the Myth of Israeli Supremacy. . . In 1967, Israeli airmen had undertaken a preemptive air attack (discussed subsequently) that secured total air supremacy over the theater of conflict. It used that supremacy to overwhelm vastly more powerful opposing Egyptian, Syrian, and Jordanian surface forces. After that war, Egypt and Syria recognized that control of the air involved more than air-to-air combat between opposing fighters. They built air defense networks integrating fighters, antiaircraft artillery, and, above all, surface to air missiles. These networks were so powerful that in 1973, they denied the kind of air dominance that Israelis had come to expect. As a result, even though Israeli pilots secured air superiority over their Arab opponents, Israel experienced serious losses that actually threatened its ability to prosecute the fast-moving war to a successful conclusion, endangered the very survival of the state of Israel, and threatened to widen the war, perhaps leading to use of atomic weapons and even a clash between the United States and the Soviet Union.

At the outset of the war, the Israeli air force numbered 309 combat aircraft, the Egyptian air force approximately 490, and the Syrian air force approximately 265. Additionally, approximately 125 aircraft were furnished from Algeria, Libya, and Iraq. Due largely to missiles (primarily the SA-2, SA-3, SA-6, and SA-7, the latter a man- 
portable weapon) and conventional high-rate-of-fire radar-directed antiaircraft cannon (the ZSU-23-4 gun carriage), over the first four days of the war, Israel lost 60 fighter and attack aircraft, approximately $19 \%$ of its combat aircraft inventory. Strike aircraft encountered intense surface-to-air missile barrages, with up to fifty missiles accelerating toward formations at the same time; as Israeli General Chaim Herzog later wrote, "The Israeli Air Force fought a desperate battle, flying into the teeth of one of the most concentrated missile systems in the world." ${ }^{55}$ So much effort had to be put into suppressing and defeating air defenses that other missions of importance to the conflict had to be placed on hold. Israel's air force had been so savaged that, in the words of analyst Yehuda Weinraub, it "could not fulfill its own expectations and those of the ground forces."

In particular, the lack of Israeli air supremacy over the northern front permitted Syrian armored forces to directly threaten overrunning Israeli forces close to the Israeli heartland. As a result, Israeli defense minister Moshe Dayan ordered a temporary redirection of the Israeli air force's effort away from the Sinai to the Syrian front, Intensive strikes on Syrian missile and antiaircraft positions, coupled with creative use of artillery to suppress enemy air defenses as well, ultimately saved the day, but it had been very close. Overall losses over nineteen days of combat were 109 Israeli aircraft (35\% of prewar combat strength), 242 Egyptian aircraft (49\% of prewar strength), 179 Syrian aircraft (68\% of prewar strength), and 21 Iraqi aircraft (26\% of the 80 Iraqi fighters sent to support the war). 
The Falklands: Relearning Old Lessons in the "Roaring Forties". . .

In 1982, Argentina invaded and occupied the Falkland Islands. Subsequently, Great Britain regained control of the Falkland Islands after a protracted air-sea campaign that hinged on control of the air. Using high-technology fighters and missiles, British airmen and seamen shot down numerous Argentine aircraft. But even though the task force possessed air superiority, it never possessed overall air supremacy: the ability to so control the air as to prevent any significant attacks against British ships.

Despite possessing good radar and communications, advanced air-to-air and surface-to-air missiles, and revolutionary V/STOL Sea Harrier fighters as well, the Royal Navy lost six ships sunk (two destroyers, two frigates, a container ship functioning as an aircraft carrier, and a fleet auxiliary) and a further thirteen damaged (four destroyers, six frigates, and three fleet auxiliaries) to older Argentine Skyhawk and Dagger strike aircraft making sporadic hit-and-run attacks. Luckily, many bombs did not explode. Of approximately 22 bombs which struck British ships, 12 failed to detonate and one detonated late; only 9 were released high enough to arm and then detonate upon impacting a ship: these nine sank two frigates, a destroyer (hit by three of the nine) and a fleet auxiliary. Thus, fully 55\% failed to explode even though they hit their targets. Had they done so, it is likely at least six of the other thirteen vessels damaged would have been lost--particularly two frigates hit by a total of six 1,000 lb. bombs.

Concern over rising British losses is clearly evident in the memoirs of key British decision makers, for the sinkings were, in the words of one Royal Navy officer, "a dreadful reminder to us all of the destructiveness of air attacks." ${ }^{7}$ Had the Royal Navy 
lost more of its antiaircraft defense vessels, the task force might have had to be withdrawn. It certainly would have withdrawn if one of its carriers (Hermes or Invincible) had been sunk or otherwise so damaged that it could not conduct flight operations, or if the major troopship Canberra had been likewise lost or damaged. The Thatcher government likely would have fallen, perhaps fatally weakening the characteristically strong alliance of the United States and Great Britain that did much to bolster European resistance as NATO faced the Soviet Union in the most serious years of the Cold War. Thus, because a first-rate military power lacked air supremacy sufficient to deny a fourth-rate military power the ability to attack its fleet units, it risked losing a war thousands of miles from Europe that might have resulted in a dramatically different end--if indeed it did end--to the Cold War. Not surprisingly post-Falklands British maritime doctrine, for example, emphatically states that: ${ }^{8}$ "The minimal requirement for a successful [maritime] operation is a favourable air situation. Air superiority will be a requirement for sea control where a robust challenge from the air is possible. Air supremacy is a necessary precondition of command of the sea." [emphasis in original text]

All of these examples illustrate that mere "air superiority" is never enough on its own, but, at best only the minimal state required for successful air operations. Air superiority may be what American and coalition air forces are forced to accept, but should never be what they willingly choose to maintain or achieve. Rather, the minimum sought should be supremacy, and, in fact, the greater manifestation of supremacy--the infliction upon our opponents of air paralysis. 
III.

\section{Air Supremacy: Dominant Air Warfare With Decisive Results}

In contrast to the disappointing or even sometimes alarming record of air superiority warfare, air supremacy warfare has always posed the more attractive, desirable, and militarily more useful option. The historical experience of air supremacy warfare clearly indicates that the ability to exert total air dominance over an opponent should be the desired "conflict entry state" for waging effective joint and coalition air warfare. An examination of various conflicts in which air supremacy played a role--from Normandy and the breakout across France in the Second World War, and on to Korea, the “Six-Day War," the 1972 air war in Vietnam, the Bekaa Valley experience, the Gulf War, and the Balkans--all offers clear evidence of how air supremacy, not mere air superiority, makes the key difference in war, even in "wars of national liberation."

\section{Normandy and Afterwards: Air Supremacy and the Destruction of the Wehrmacht}

There are many examples that make the air supremacy case, but perhaps the best example of all, particularly given the powerful emotional appeal and widespread public acceptance of the Stephen Spielberg film Saving Private Ryan, is the Normandy invasion of 1944 and the subsequent campaign in Western Europe. From the outset of the Normandy landing, control of the air meant everything. To achieve it, early in 1944, the Allies concentrated--and succeeded--in destroying the Luftwaffe as an effective counterinvasion force. Fully $25 \%$ of Germany's total fighter pilot force (an average of approximately 2,300 at this time) perished in May 1944 alone; in each of three successive months, March, April, and May of 1944, an average of 50\% of the available German 
fighters that month were lost, largely to the depredations of marauding fighters. As a result, less than a month before the invasion, Army Chief of Staff George Marshall could stated with confidence "We are about to invade the continent and have staked our success on our air superiority, on Soviet numerical preponderance, and on the high quality of our ground combat units." 9

Even before the actual invasion, German military leaders had complained about the increasing absence of the Luftwaffe; Rommel's naval aide, Vice Admiral Friedrich Ruge, confided in his diary over a month before D-day that the disparity between the Luftwaffe and the allied air forces was "humiliating." 10 As a precaution, when the actual invasion began on June 6, 1944, fully 102 squadrons of Allied fighters patrolled the skies above the invasion fleet, the landing area, and deep into France to guard against Nazi fighters and bombers. But the Luftwaffe was powerless to intervene. General Adolph Galland, the former chief of German fighter forces, wrote after the war that on the morning of the invasion, "Allied fighters formed a solid air umbrella over the landing sector, and they sent up fighter forces outside the invasion area which closed off the whole zone. Only in two instances, on the first day of the landing, did German fighterbombers penetrate the defensive frame and the air umbrella and drop their bombs on the bridgehead. From the very first moment of the invasion the Allies had absolute air supremacy. Therefore the enemy, our own troops, and the population asked the obvious question, "Where is the Luftwaffe?",11

Unprotected from above, German ground commanders discovered immediately what the loss of air control meant for their mobility. German Lieutenant General Bodo Zimmerman, the chief operations officer of Army Group D, noted that once a morning 
fog had dissipated on that fateful day, "the whole of the area through which the [German] divisions must march was being most intensively patrolled by the Allied air forces. No road movement by day was possible in view of this air umbrella, which reached from Normandy to the Paris area." ${ }^{\prime 2}$ Things only became worse over succeeding days. Despite efforts to intervene, the Luftwaffe remained on the defensive. Galland recalled that "Whenever a fighter plane rolled out of its camouflaged lair, an enemy immediately pounced on it. The danger of being detected and destroyed by the enemy was ever present. At last we retired into the forests. Before and after each sortie the planes were rolled in and out of their leafy protection with great difficulties and much damage. ... Fourteen days after the invasion the units had sunk so low in their fighting strength that neither by driving the personnel nor by material replacements could they be put on their legs again." ${ }^{.13}$ Surveying the invasion landing area late in June 1944, when the beaches were still strewn with men and material and utterly vulnerable to an opponent who could have mounted a serious air attack against them, "Ike" Eisenhower's son John remarked "You'd never get away with this if you didn't have air supremacy." "Without air supremacy," Ike replied sharply, "I wouldn't be here."14 Eisenhower recognized that he had something that went far beyond conventional "air superiority." His air forces so dominated the Nazis that, to a great extent, the surface combat forces did not have to really concern themselves about enemy air intentions.

On the other side, German commanders at the time, and writing after the war, were shocked at how Allied control--indeed domination--of the air limited their ability to function. Germany's famed "Desert Fox," Field Marshal Erwin Rommel, commander of Army Group B, remarked “the enemy's air superiority is having a grave effect on our 
movements. There's simply no answer to it." On July 17, a Canadian reconnaissance pilot looking for German road traffic spotted his Horch staff car, and (not knowing the identity of its passenger but realizing that a staff car likely contained an important traveler) reported its movements. Two Spitfires responded and strafed it off the road, seriously injuring Rommel and removing him from the war. ${ }^{15}$ Field Marshal Hans Guenther von Kluge, the commander-in-chief of Nazi forces in the West, succeeded Rommel as commander of Army Group B following Rommel's injury. Assessing what was happening, he despairingly wrote to Hitler that "in the face of the total enemy air superiority, we can adopt no tactics to compensate for the annihilating power of air except to retire from the battlefield." ${ }^{16}$ Subsequently, exactly a month after Rommel's crash, Von Kluge committed suicide while enroute to Germany after being removed from command following his implication in the von Stauffenberg bomb plot against Hitler. His successor as chief of Army Group B was Field Marshal Walter Model. In his postwar assessment Zimmerman wrote that Model "did not immediately grasp the full gravity of the situation in France and hoped that he might yet restore it. But he was soon to realize the unimaginable effects of the enemy's air supremacy, the massive destruction in the rear areas, the impossibility of travelling along any major road in daylight without great peril, in fact the full significance of the invasion." 17

Protected from significant German air and surface attack, all other combat forces were able to function with maximum efficiency. In early August, eight German armored and infantry divisions attempted and failed to break through Allied lines at Mortain. In his official after-action report, Eisenhower wrote "The chief credit in smashing the enemy's spearhead must go to the rocket-firing Typhoon planes of the Second Tactical 
Air Force. ... The result of this strafing was that the enemy attack was effectively brought to a halt, and a threat was turned into a great victory." ${ }^{\prime 18}$ After Mortain, German forces sought to flee back to the French frontier. Over the next two weeks, across the Falaise-Argentan gap, air power took a terrible toll of German troops and equipment. Major General Rudolf-Christoph von Gersdorff stated "very strong” air attacks "caused high losses. . . units of the Army were almost entirely destroyed by low flying attacks and artillery."19 Touring the area afterwards, Eisenhower likened it to "scenes that could only be described by Dante."20 Over 10,000 Nazi soldiers perished, and more than 50,000 were taken prisoner; one country road earned the grim name le Couloir de la Mort: "The Corridor of Death.” (Some German soldiers desperately attempted to surrender to attacking Allied aircraft by displaying white flags). Hundreds of tanks and artillery pieces were destroyed or abandoned, and other vehicle losses exceeded 2,500. In sum, Germany's forces had been broken, largely by Allied air attackers free to operate unmolested by a Luftwaffe harried from the sky by Allied air supremacy.

In addition to Normandy, air supremacy played a major role in the defeat of the Third Reich over the fall and winter of 1944-45, particularly in the Ardennes offensive, the famed "Battle of the Bulge," which shattered all hopes for any miraculous Nazi victory. After the war, the major German commanders in the Ardennes were unanimous in their view that it had been allied air power which played the most significant role in the frustration of their plans. Major General F. W. von Mellenthin, the chief of staff of the Fifth Panzer Army, stated "The Ardennes battle drives home the lesson that a large-scale offensive by massed armor has no hope of success against an enemy who enjoys supreme command of the air." 21 The commander of the German offensive, Field Marshal Gerd 
von Rundstedt told allied interrogators "that the main reason for the failure of the Ardennes offensive was his own lack of fighters and reconnaissance planes," in short, the Luftwaffe's failure to retain control of the air. ${ }^{22}$ General Hasso von Manteuffel, commander of the Fifth Panzer Army, noted that the Allied success at the Bulge stemmed from quicker reaction to the attack than German planners anticipated, better coordinated countermeasures, and "the same unlimited air supremacy" as the Allies had possessed at Normandy. ${ }^{23}$

As at Normandy, with the skies secure, all other military operations were more productive, particularly air-to-ground attack. After the war, $12^{\text {th }}$ Army Group commander General Omar Bradley stated that, during the opening defensive phase of the Bulge, "the greatest benefit derived from the tactical air force was in the offensive action of the fighter-bomber in blunting the power of the armored thrust, and striking specific targets on the front of the ground troops." 24 Fuel strikes produced immediate effects on German mobility. In one case, the destruction of one tanker truck carrying three tons of gasoline kept one SS Panzer division from seizing Liege. ${ }^{25}$ General Fritz Bayerlein, formerly Rommel's chief of staff and a commander of a Panzer division in Normandy and the Bulge, "particularly noted the disastrous and calculated selection of fuel tank trucks as fighter-bomber targets. He and others have vivid memories of precious forward gasoline dumps lost through air attack." 26 The combination of fuel and interdiction attacks destroyed German mobility. Manteuffel recalled that the Allied air forces "found worthwhile targets throughout the whole area of our offensive. Bomb carpets were laid down on the roads and railways behind the front, and our already inadequate supply system was throttled. The mobility of our forces decreased steadily and rapidly."27 
Reflecting on the Bulge and other experiences where air attack had hindered or denied mobility, German Generals von Kluge Bayerlein, and von Rundstedt agreed “when mobility and maneuver are lost, the loss of battles and campaign follows."28

In short, Allied air supremacy over Normandy and the Ardennes produced conditions whereby both air-to-ground attackers and surface forces could exploit their fullest capabilities against the foe. Given that (in Bradley's words) "From the high command to the soldier in the field, German opinion has been agreed that air power was the most striking aspect of allied superiority," ${ }^{29}$ Allied air supremacy must be considered the decisive key factor ensuring the success of the Allied ground campaign--and saving many "Private Ryans" along the way--from Normandy's beachhead to the utter destruction of the Wehrmacht in early 1945 and the subsequent fall of the Third Reich.

\section{Sabre vs. MiG: Air Supremacy's Influence on the Korean War}

At the outbreak of the Korean War in 1950, North Korean forces attempted to seize control of the air using older Russian-built propeller-driven Yak and Lavochkin fighters. First-generation American F-80 Shooting Star and F9F Panther jet fighters quickly dominated them so that within several days, the North Korean Air Force was not a significant factor. With control of the air assured, Allied commanders could concentrate on winning the surface battle. Unhindered by enemy aircraft, land-and-seabased air attackers pounded advancing North Korean tank and infantry units. In the absence of large defending ground forces, this air action both protected what few (and generally under-armed, trained, and equipped) forces were on the ground from being overrun, and decimated enemy formations. By mid-September 1950, the North Korean forces were halted, and, in the middle of the month--again ably supported by free-ranging 
air strikes--General Douglas MacArthur launched his famed Inchon invasion that forced remaining North Korean units into a hasty retreat.

When China intervened in the late fall, sending MacArthur's troops retreating southwards, the presence of massive American and coalition air support prevented the retreat from disintegrating into a rout. Further, the aerial attackers took a significant toll of the advancing Chinese forces, helping to stabilize the front and set the stage for Allied counterattacks that regained all of the South Korean territory lost by this "second invasion." When Russia attempted to contest control of the air by sending large numbers of its fighter pilots and the new sweptwing MiG-15 into combat (an airplane superior to the early American Air Force and naval jet aircraft then in theater), the United States responded with its own sweptwing F-86A Sabre. An elegant design, the Sabre, though it could not climb as high or as swiftly as the lighter MiG, had far superior high-speed flying qualities and a better gun and sighting system.

Thereafter, an intense attritional air war was fought in the far northwestern corner of North Korea, a region known as "MiG Alley." In this fighting, while Boeing B-29 Superfortress bombers could strike below the Yalu river and thus prevent the North Korean Air Force from using airfields close to the fighting, they were prohibited from operations above the Yalu, in Manchuria, which thus became an important sanctuary for MiG-15 operations. Further, the number of MiG's at any one time greatly outnumbered the number of Sabres. For example, in June 1952, the Communists were fielding approximately 1,000 MiG's, while the two Sabre fighter wings committed to the war numbered a total of only 163 Sabres--an enemy-to-friendly ratio of over $6: 1$. Despite this, F-86 pilots--exploiting their fighter's transonic superiority coupled with their own 
generally better pilot training--were credited with shooting down a total of $792 \mathrm{MiG}-15$ 's for a loss of 78 Sabres: a victory-loss ratio over the MiG of over $10: 1$. (Overall, 954 enemy aircraft of all sorts fell to American Air Force and naval pilots, for a price of 147 friendly aircraft of all sorts shot down, a victory-loss ratio of $6.48: 1$ ).

Thanks to the Sabres containing the MiGs (which otherwise might have enabled organized Communist ground attack operations against United Nations forces), UN troops fought without any fear of systematic enemy air attacks upon their positions right up until the Korean armistice in July 1953. Thus shielded, they were able to undertake extensive resupply, basing of forces, training, and combat activities "in the open." (Those Communist attacks that were made were sporadic night harassment strikes by an individual biplane or other light aircraft dropping grenades and small bombs on airfields close to the front). Possessing complete control of the air over the fighting front, UN airmen were free to devote their fullest attention to attacking Communist positions and supply lines, with results generally similar to those experienced by the Germans in Normandy and afterwards: postwar analysis has credited air attack with inflicting the majority of Communist losses: $47 \%$ of enemy troops killed, $75 \%$ of tanks destroyed, $81 \%$ of trucks lost, and $72 \%$ of artillery destroyed. In contrast to the UN forces, the Communists had to divert tremendous resources into trying to defend themselves with antiaircraft cannon, concealment of forces and supplies, and laborious movement of materiel and goods. All this diverted significant manpower and armament resources that might otherwise have been applied to the battle at the front, possibly with decisive effect. In sum, American air supremacy in Korea was absolutely critical to prosecuting the joint 
force and coalition campaign that succeeded in keeping South Korea free from domination by the North.

\section{The Six-Day War: Air Supremacy via Preemptive Strike}

From virtually the moment of creation of the small state of Israel in 1948, offensive air power had been the decisive key to the nation's survival. Israel's bestknown airman, Gen. Ezer Weizman, often remarked "We shall defend Tel Aviv over Cairo." ${ }^{30}$ As commander of the Israeli Air Force from 1958-1966, following the Suez War of 1956, he had ensured that the development of the Israeli air arm followed this "offensive defense" rationale. As a result, by 1967, Israel possessed a small but extremely professional and powerful regional air force organized, trained, and equipped to Western standard, and built around a core of advanced French combat aircraft.

On the morning of June 5, 1967, in the face of rising tensions, a blockade of the Straits of Aqaba, and calls for an Arab war against Israel, the Israeli air force, then under the command of Gen. Mordechai "Motti" Hod, put this philosophy into practice. At approximately 0700, Hod launched a preemptive air assault against the combined Arab air forces, beginning with concentrated strikes against Egypt, then Jordan and Syria, and, finally, Iraq. Altogether 28 different Arab airfields were brought under attack. In a matter of hours, all of these air forces had, for practical purposes, been put out of commission. Because of its size and force structure--approximately 450 fighters and bombers and 130 others--Egypt posed the greatest threat, but, even in this case, by 10:00 a.m., Weizman, chief of operations on the Israeli general staff, felt free to call his wife and proclaim "We have won the war!" 31 After making a circuitous approach over the sea at an altitude of 100 feet, the first wave of attackers had destroyed the Egyptian air force 
in a mix of low-altitude air attacks through radar gaps, use of special runway denial bombs, rocketing, strafing and bombing of hangar and revetment areas, and a small number of air-to-air combats. Follow-on attackers completed the destruction, and then, just after noon, turned their attention to the other air forces. By mid-afternoon Israel's leadership had essentially no further fear of significant Arab air action directed against their country or its combat forces then sweeping across the Sinai.

An examination of opposing forces clearly indicates how vital this preemptive strike was to Israeli success, particularly since the Israeli air force was at technological parity with their regional rivals, but also a serious quantitative disadvantage. At the outset of the war, Israel possessed a total of 297 combat aircraft, and the Arab states a total of 748. The total number of Israeli air superiority fighters of all types was 96, and the total number of air superiority fighters in Arab service was 579. Israel's most sophisticated and advanced air superiority fighters were 72 French-built Dassault Mirage IIICJ; in addition, the force possessed 24 older Dassault Super Mystère fighters. The most advanced threat aircraft arrayed against them were potentially $176 \mathrm{MiG}-21 \mathrm{~s}, 95$ of the only slightly less capable MiG-19, and 5 Lockheed F-104A Starfighters (the latter, delivered to Jordan, were prudently flown out of the country prior to the war). Thus, overall, Israel faced a disparity ratio of slightly over $2.5: 1$ in total combat aircraft, an overall air superiority fighter disparity ratio of slightly over $6.0: 1$, and a "top-end" fighter disparity ratio of Mirage IIICJs vs. MiG-19/21 aircraft of $3.76: 1$.

As a result of the preemptive strike, Israel gained immediate air supremacy over its foes. While Israel was not able to totally suppress subsequent Arab air force attacks on Israeli forces, its airmen had been able to ensure that Israel faced no danger of Arab 
bombing attacks against the Israeli heartland, or coherently organized attacks against its fielded forces. The few sporadic strafing and light bombing attacks flown over the next few days against Israeli ground forces were, at worst, an annoyance rather than a hindrance. Israeli air supremacy for subsequent military operations in the campaign had been assured, for the opening air strikes had witnessed at least 300 Arab aircraft lost for less than 20 Israeli combat aircraft, a ratio of $15: 1$.

Over the remaining days of the war, Israel consolidated its aerial victory. By war's end, the Arab air forces had lost a total 452 aircraft destroyed, representing over $60 \%$ of their combined prewar combat air strength. Of Arab losses, only 79 (17\% of total losses) were shot down, including 50 (11\% of total losses) destroyed in dogfights, and 29 lost to conventional antiaircraft fire or other causes (6\% of total losses) confirming both the success of a Israeli air strategy aimed at catching the enemy on the ground, and the small Arab air effort that followed the devastating opening Israeli air assault. Arab losses included 318 of 579 air superiority fighters (-55\%), and 63 of 98 bombers of all types ($64 \%$ overall; this included $100 \%$ of Egypt's most dangerous threat bomber, the Tupolev Tu-16, all thirty of which were destroyed on the ground, as well as the shoot-down of the sole Iraqi Tu-16 sortie). In particular, the Arabs had lost 163 of $271 \mathrm{MiG}-19 / 21 \mathrm{~s}$ (60\%), consisting of 132 of $176 \mathrm{MiG}-21 \mathrm{~s}(-75 \%)$ and 43 of $95 \mathrm{MiG}-19 \mathrm{~s}(-45 \%)$.

In contrast, Israel had lost a total of 46 aircraft, representing 15\% of its prewar combat air strength. Though sources vary, apparently air-to-air losses numbered only 10 aircraft (22\% of total losses), the remaining 36 (78\% of total losses) being felled by conventional antiaircraft fire. Overall Israeli losses included 10 of its 96 Mirage and Super Mystère air superiority fighters (-10\%), consisting of 6 Mirages (-8\%) and 4 Super 
Mystère (-17\%) and 5 of 25 Sud Vautour II light bombers (-20). A total of 26 pilots were killed, with a further eighteen wounded.

On the other hand, with air supremacy assured, Israeli ground attack forces and "swingrole" air superiority forces now turned to ground attack duties. In particular, they undertook concentrated and devastating air attacks against Egyptian mechanized formations. Echoing the Allied experience in Normandy, the Israeli chief of staff, General Yitzhak Rabin, stated "The air strikes destroyed not only tanks but the ability of the Egyptian armor in general to remain mobile." 32 The casualties inflicted by these attacks, and from subsequent follow-up by Israeli ground forces, were enormous, particularly during the destruction of Egyptian columns at Mitla Pass. Overall, Arab losses totaled approximately 43,500 killed, wounded, and missing, with approximately 1100 tanks, 650 artillery pieces, and 10,000 other vehicles destroyed or captured. For its part, Israel lost over 700 dead and approximately 3,900 other casualties in the war.

In conclusion, the Six-Day War must be seen as a cautionary tale, and four lessons stand out:

--First, because Israel possessed air superiority fighters only as good as-and not better than--its opponents (as well as being numerically deficient), its national leadership could not afford to wait for an Arab attack but, rather, had to engage in a preemptive strike, risking disastrous failure as well as possible global opprobrium. (This echoes, in some respect, the "launch on warning" dilemma in nuclear strategy).

--Second, a nation with high-quality aircraft and highly trained and motivated personnel can get in a first strike against other nations possessing 
equally high quality equipment (even if with deficiencies in quality personnel), and even a strong numerical advantage, and so alter the nature of a conflict as to reverse its anticipated or expected outcome.

--Third, the outcome of such an air-dominated conflict can be an entirely transformed geo-political situation: in this case, Israel went from being the clear "underdog" to the dominant military power in the region, and has remained so to the present day.

--Fourth, and most importantly, the experience of the Middle East war of 1967 teaches that once a nation loses control of the air, it is utterly vulnerable to whatever an enemy attacker wishes to do to it. That lesson would be repeated and relearned, before a global television audience, with the Gulf War of 1991.

Vietnam, 1972: Air Supremacy and Halt Phase Warfare

In 1972, North Vietnamese tank and infantry forces undertook a bold offensive to forcibly seize control of South Vietnam. Against the expectations of air power critics, coalition air power was notably successful in confronting this conventional offensive, and then, in the well-known Linebacker II strikes later that year, in setting the conditions for North Vietnam's return to the peace talks in early 1973. Of these two episodes, the least appreciated historically is the important role that air power played in confronting the socalled "Easter offensive" of 1972.

Throughout the long years of the Vietnam war, the overwhelming bulk of air effort was devoted to the war in South Vietnam itself. Over that time period, air support and airlift operations in South Vietnam proved of tremendous value and, on many occasions, prevented the seizure and loss of hamlets and other key facilities that 
otherwise would have been overrun by the Viet Cong or the North Vietnamese Army. Direct air support to friendly forces engaged in close combat with Communist forces often proved the critical factor between survival and defeat. Here the tremendous availability of tactical air power resources was of profound significance: virtually every spot in South Vietnam was within a fifteen minute flight of jet aircraft located at bases across the country.

Given the failure of the Viet Cong to seize control in the South, if Hanoi were to take-over the South, North Vietnam's military forces had to (at some point) come out in the open and mount a successful, conventional assault, using all the accoutrements of a modern military power. The challenge North Vietnam's army regulars in the south faced was daunting: to fight in the open they would have to either defeat available American and South Vietnamese air power, or survive under its withering attacks. Air attack generally intimidated and often terrified North Vietnamese regulars and South Vietnamese Viet Cong forces alike, consistent with the history of air attack against other armies in virtually all air wars of this century. One $V C$ leader recalled that "The truth was that we were losing more than we were winning. . . there was an unspoken feeling that we couldn't win now that the Americans were there. They were just too stronghelicopters, jets, B-52's. How could you beat them?"33 Another recalled "One of the things that demoralized a lot of guerrillas were the B-52 attacks. The fear these attacks caused was terrible... .[people] would come out of their bunkers shaking so badly it looked as if they had gone crazy." 34 Their opportunity seemed to come in 1972, as the American ground presence in South Vietnam wound down, and South Vietnam was left to defend itself solely through a dwindling number of American air units and its own air 
force and army resources. At this time, North Vietnam's leaders hoped they could take advantage of the absence of American ground forces and the reduction in air strength to wrest control of the South away as quickly as possible.

In March 1972, North Vietnam invaded the South by a conventional mechanized assault of well over 100,000 troops, protected by mobile surface-to-air missile and conventional antiaircraft systems. The NVA forces sought to confront remaining Allied air power with an air denial strategy, such as had worked for the Viet Minh at Dien Bien Phu nearly two decades earlier against the French. They built their strategy around advancing with massive antiaircraft support including, for the first time in Southeast Asia, hand-held SA-7 SAMs. They even planned shifting mobile SA-2 batteries southwards to create "SAMbushes" and air denial zones preempting aircraft and helicopters from having access to the battle area. Using such tactics, they hoped that the bulk of their mechanized forces could be used to close and overwhelm hard-pressed South Vietnamese defenders.

But instead of victory, North Vietnamese forces received a crushing defeat. Coalition airmen flew 50,000 sorties against the invasion force, including attacks against tanks and mechanized vehicles by fighters using laser-guided bombs and helicopter gunships firing anti-tank missiles. B-52 bombers, complemented by smaller aerial attackers, devastated North Vietnamese regulars massing to attack An Loc, the keystone to seizing Saigon. One U.S. Army general called the B-52 "the most effective weapon we have been able to muster. ... if [the enemy] does mass his forces, he takes terrible casualties. ${ }^{, 35}$ Down south, North Vietnam's offensive ground down to a halt amidst truly bitter fighting. 
Meantime, thanks to better rules of engagement and tactics than had been employed during the bankrupt days of Rolling Thunder, the air campaign, called Linebacker, was achieving impressive results of its own. Better fighter training and experience meant that MiG's that were engaging strike forces were being shot down at close to an average of one shootdown per engagement, for the first time in the war. Strike aircraft, amply protected by fighter screens and electronic warfare and SAM-killers, and using a revolutionary new weapon, the laser-or-electro-optically-guided "smart" bomb, halted all rail traffic south of Hanoi, shut down power, and mined the port of Haiphong. These strikes had a devastating impact on the ability of the North Vietnamese to supply their forces in the south, as noted in the official Vietnamese history of the war: "Because the enemy had escalated rapidly, was bombarding us massively, and was using many types of new weapons ... many units and local areas suffered heavy losses. Almost all the important bridges on the railroad and on the road corridors were knocked down. Ground transportation became difficult. Coastal and river transportation were blocked." ${ }^{36}$ However desperately they fought, North Vietnam's troops remained unable to carry the day; though fighting continued all summer, but by late May, the tide of conflict was running increasingly in favor of the American and South Vietnamese defenders. The majority of North Vietnamese forces withdrew, having sustained (by some accounts) more than $50 \%$ casualties to their invasion force, as well as the loss of more than half of their tanks and artillery.

In short, because the North Vietnamese air force and air defense forces were not able to maintain control of their own airspace, and because the North Vietnamese forces fighting in the South were not able to successfully use their surface-to-air missile and 
antiaircraft forces to deny control of the air to Allied defenders, Hanoi's plans were utterly frustrated. At the end of 1972, following the Linebacker II campaign, which inflicted even greater damage on Vietnam's military infrastructure, and utterly shattered its air defense system, North Vietnam returned to the peace talks in Paris. The invasion had to wait for a more propitious time, following extensive rebuilding of forces. That came three years later when, in the absence of any significant air power opposition, North Vietnam overran the South in only six weeks.

\section{The Gulf War: The Reaffirmation of Air Supremacy}

Operation Desert Storm, in the words of one student of air power, "marked the apotheosis of twentieth-century airpower. ${ }^{, 37}$ President George Bush, speaking at the Air Force Academy in 1991, stated it more bluntly: "Gulf Lesson One," he said, "is the value of air power." ${ }^{38}$ The Gulf War represented the first time in American experience when an air war had made such an overwhelming impression on the average citizen as to make possible a general acceptance that air power had been, without question, the war's decisive factor. This was signaled both by professional journals and news media accounts, as well as popular culture. An overnight express mail service ran television ads with actor Jonathan Winters playing a Norman Schwarzkopf-type character and briefing on the importance of "air superiority." The popular cartoonist Jeff MacNelly had an elementary school student answer the test question "Why did the South lose the Civil War?" "There were a lot of reasons why the South lost the war," the kid replied, "but the biggest reason would have to be the obvious one: they failed to achieve air superiority." In the fall of 1990, this cartoon would have made no sense to its readers. In 1991, after the Gulf War, it needed no further explanation. 
What happened to Iraq in 1991 was unprecedented in American experience, but the roots were wedded in earlier air supremacy warfare back to Normandy. In particular, however, the Iraqi experience mirrored what Israel had possessed at the end of the first day of the Six Day War, but updated to reflect later experience and technological capability, and the bitter lessons of the 1973 Arab-Israeli war. The first indication that Western-style air forces had learned from the 1973 Arab-Israeli war came with the short and very intense 1982 Israeli air campaign against Syrian surface-to-air missiles sites and the Syrian air force, fought over Lebanon's Bekaa valley, an area the size of Luxembourg. Concerned lest its ability to operate over Lebanon in support of an on-going Israeli ground offensive against the Palestine Liberation Organization be compromised by Syrian air defense intervention, and faced with evidence that Syria was reinforcing no less than nineteen SAM sites in the Bekaa, the Israeli air force took the SAM sites under attack, triggering clashes as well with intervening Syrian air force.

But unlike in 1973, Israel went to war over the Bekaa valley using an integrated approach involving airborne command and control, use of small unmanned air vehicles to gain tactical intelligence, comprehensive anti-SAM "Wild Weasel"-style operations, and electronic combat. The result was a swift and sudden domination of Syrian forces that blinded their command and control and left them utterly vulnerable to attack. In two days, Israeli attackers destroyed all nineteen surface-to-air missile sites, and shot down 64 Syrian fighters. Before fighting ended several weeks later, a further 21 fell to Israeli fighters. Of these 85 downed Syrian fighters (including MiG-21, 23, 25, and Su-20 aircraft), F-15s shot down 40, F-16s 44, and a F-4 destroyed 1. It was a hint of what the new "superfighter" generation of aircraft could do against technologically less 
sophisticated opponents, but also an indication of how the combination of excellent intelligence, command and control, tactics, training, and equipment could work together to produce air domination over an opponent. That would be demonstrated even more dramatically, against a far more competent and sophisticated opponent, not quite nine years later.

In 1991, Iraq possessed the sixth largest air force in the world. It had over 950 aircraft, including 405 air superiority fighters (Mirage F-1Es, MiG-23s, MiG-25s, and, primarily, MiG-21s), and 265 ground attack aircraft (many of which were older fighters). Its airmen flew from 24 main airfields and 30 dispersal bases, all well protected; overall, Iraq possessed 16,000 surface to air missiles (including SA-2, SA-3, SA-6, SA-8, and French Rolands, but not including numerous SA-7 and SA-14 shoulder-held missiles), and 7,000 antiaircraft guns. A specialized command and control structure--the Frenchbuilt KARI network--linked the various nodes of the air defense system. KARI joined early warning sites reporting to multiple interceptor operations centers that, in turn, reported to five sector operations centers that, finally, reported to an air defense operations headquarters in Baghdad. Even allowing for Iraqi deficiencies in organizing, training, and equipping their military forces, defeating an air defense network of this size and complexity demanded a well-thought-out and multifaceted campaign for air control. As General Charles Horner recalled in his memoirs, "To me, the goals of the air superiority campaign were threefold: (1) To render the Iraqi fighters inoperable. We would blind the by cutting off their command and control, terrorize them by shooting down anything that flew, and make life difficult by bombing airfields and radar sites. (2) To render the radar guided surface-to-air missiles impotent. We would attack command 
and control and use support jamming EA-6Bs and EF-111s, in order to force each piece of the system into autonomous operations (in that way they had to radiate with their own radars to find a target, making them more vulnerable to HARM [antiradar missile] attacks). We would terrorize the operators to induce them not to use their radars. We would kill them on a priority basis, using Wild Weasels and USN HARM-equipped aircraft. We would self-protect by using ECM pods, and by flying in VFR conditions, so aircraft could see the radar-guided SAMs and out-maneuver them. (3) To render guns and shoulder-fired [infrared] SAMs useless. We would fly at medium altitude; keep the time at a low altitude (such as at the bottom of a dive bomb pass) at a minimum; and--the age-old lesson we always relearn in combat--we would not make multiple passes on the same target." 39

If the coalition had attempted to gain control of the air by conventional means-fighting the Iraqi air force aloft, and taking down each of its functioning surface-to-air missile sites while they were up and functioning fully, would have been a daunting as well as costly task. Instead, planners relied on a decapitation strategy: first, F-117 stealth fighters would attack the integrated air defense sector operations centers and Iraqi air defense headquarters. With Iraq's command system presumably disrupted, a large package of non-stealthy air defense suppressors would then surge towards Iraq; groundand-air-launched decoys modified to mimic the radar return of piloted aircraft would further confuse Iraqi defenders, who would receive the impression they were about to be overwhelmed by a huge "gorilla" conventional attack package. Hopefully this would panic them into operating virtually all their radars in an attempt to target and destroy the decoy "attackers." Then, SAM-killing "Wild Weasels" would target all these radiating 
emitters with anti-radar missiles, blinding the defenses. With the air defense network in chaos, opportunistic follow-on attackers would pour through the gaps in defenses and attack other sites such as airfields. Over all this, squadrons of fighters would sweep to intercept any Iraqi aircraft that did take off and attempt to interfere with the night's air operations.

In fact, this plan worked as planners intended. By the next morning, in the arguably overly conservative words of the Gulf War Airpower Survey's Summary Report, "Air superiority was achieved by the end of 17 January 1991; by 27 January, General H. Norman Schwarzkopf, Commander, Central Command, could declare air supremacy, meaning that the Iraqi Air Force no longer existed as a combat-effective force." ${ }^{\circ 0}$ For his part, the Central Command Air Forces commander, Gen. Charles Horner, recalled subsequently, "When did we get air superiority? We had it before the war began, because we had the means to get it--equipment, intelligence, training, and the courage of the aircrews. ... But do not get the idea that gaining control of the air was easy. It was not a 'macho,' 'no sweat' operation. What turned into a turkey shoot in late January and February started out as a bitter struggle; those first few days were the hardest-fought, most critical aspect of the entire war." ${ }^{41}$

Eight Iraqi fighters fell to Air Force and Navy fighters on opening night of the war, and a further eight by the end of the first week. At that time, the coalition began attacking the Iraqi air force in its shelters; for three days little happened and then, on January 26, the ninth day of the war, the Iraqi air force began fleeing to Iran. By the end of the war, coalition fighters had shot down 35 Iraqi aircraft for the possible (but unconfirmed) loss of a single Navy F/A-18 to an Iraqi MiG-25; another 200 had been 
destroyed on Iraqi airfields, while 120 others had flown to Iran. Of a total of 594 hardened aircraft shelters, 375 had been destroyed. In turn, the coalition had lost 38 airplanes to Iraqi defenses, with a further 48 damaged.

But more significantly, demonstrating how thoroughly the coalition had secured control of the air, only one of those lost--a Navy F/A-18 Hornet--had possibly fallen to an Iraqi fighter (a MiG-25, on opening night); all the rest were from missiles or antiaircraft fire, and, of these, only 13 were by radar-guided surface-to-air missiles, again a measure of how totally coalition attackers shattered Iraq's air defense network. Before the war, optimistic air planners estimated that losses would range from one-half of one percent of all sorties, 150 aircraft given a 30,000 sortie campaign. Others anticipated 2\% (similar to the Israelis in 1967), or up to $4 \%$; pessimists ran up as high as $10 \%$, equivalent to RAF Bomber Command or the $8^{\text {th }}$ Air Force in 1943. (In fact, the Air Force lost 14 aircraft in the war, none air-to-air, giving a loss rate of one-twentieth of one percent). The tactics of the air war had negated any chance Iraq might have had of emulating the success of the North Vietnamese in using SAMs, or that of the Arab coalition in the 1973 Arab-Israeli war. Instead, as the Gulf War Air Power Survey's summary report states, "The Coalition's loss rate was only about 1 fixed-wing aircraft per 1,800 combat sorties. This loss rate was 4.7 times lower than that experienced by the United States over North Vietnam from January-December 1967 and some 14 times lower than that American air forces sustained during Linebacker II., ${ }^{42}$

The rest of the Gulf War story is well-known. With control of the air assured virtually from the first night of the war, all other military operations went smoothly. Like Eisenhower at Normandy, Schwarzkopf had more than air superiority, he had a clear case 
of air supremacy. For the remainder of the war, Iraqi forces were pinned in place, denied mobility, robbed of effective command and control, and left without the opportunity to pursue their own strategic options or any military significant war aim. Saddam Hussein had to abandon his hopes of turning Kuwait into Iraq's "Nineteenth Province," and, finally, forty-three days after it began, Desert Storm was over. Summing up, former Secretary of Defense William Perry stated, "In Desert Storm we had air dominance. That air dominance allowed our strike aircraft to devastate the enemy air forces, and, at the same time, allowed our ground forces to operate without any air interdiction. Desert Storm taught us something about air dominance. We had it, we liked it, and we're going to keep it."43

The Balkans: Old Lessons, New Implications

Since the Gulf War, the United States and its coalition allies have gone to war in the Balkans. Here, too, the importance of waging air supremacy warfare has been reaffirmed. In October 1992, in response to the fighting in the former Yugoslavia, the United Nations passed Resolution 781 banning military flights over Bosnia. Following numerous Serb violations, the UN asked NATO to enforce the no-fly zone area in April 1993, which became Operation Deny Flight. In addition to American fighters, aircraft from Great Britain, France, the Netherlands, Spain, and Turkey also participated. On February 28, 1994, six Bosnian Serb Super Galeb attack aircraft bombed Muslimoccupied areas. Two USAFE F-16C pilots shot down four of the Galebs, as the other two fled; it was NATO's first shot “in anger” since its formation 45 years before.

As a result of this action, the Bosnian Serbs made no more attempts at bombing. Instead, the Serbs increasingly relied on surface-to-air missiles; the following April, for 
example, a Serbian missile brought down a British Sea Harrier. A variety of incidents ensued as NATO attempted to apply air power within the confines of the United Nations' clumsy and largely unresponsive command and control procedures. On November 21, 1994, forty NATO aircraft struck at Udbina airfield, while other aircraft struck at surfaceto-air missile sites. But though subsequent sorties revealed the presence of additional missile sites that could endanger relief operations or air attacks, the United Nations leadership refused NATO permission to undertake comprehensive suppression of these enemy air defenses. The UN, in short, was acting as a serious check on NATO's ability to prosecute meaningful military operations. NATO thus wisely declined to place its aircrews and aircraft at risk under these circumstances. A brief and uneasy cease-fire brokered between the warring parties by former President Jimmy Carter collapsed in May 1995 in the face of a Croatian offensive into Slavonia, Serbian counterassaults, the Serb shelling of Sarajevo and Tuzla, the Serbian seizure (for the second time) of several hundred UN peacekeepers as hostages, the NATO bombing of a Serbian ammunition depot at Pale, the shootdown and subsequent recovery of F-16 pilot Scott O'Grady, and, finally, in July, the Serbian overrunning of two safe areas, Srebrenica and Zepa, and the UN abandonment of a third, at Gorazde.

Quite clearly, UN policy in the Balkans had failed. In late July, Great Britain, the United States, and France met in London, determined to protect Gorazde (and subsequently Sarajevo, Bihac, and Tuzla as well) at all cost, particularly since numerous inhabitants of Srebrenica had been murdered after that safe area had been overrun. Under pressure from these nations and the NATO leadership, UN Secretary General Boutros Boutros-Ghali agreed to looser restrictions on air strikes. Then-Lt. Gen. Michael E. 
Ryan, the commander of Allied Air Forces Southern Europe, had supervised preparation of an air campaign plan intended to protect UN safe areas and strike at the war-making potential of Serbian forces. A brutal shelling of Sarajevo on August 28 triggered rapid approval of retaliatory action. On August 30, this air campaign, called Operation Deliberate Force, got under way. The opening days' strikes were heavy enough that Serbian President Slobodan Milosovic contacted Janvier, requesting a bombing halt. Janvier concurred, and a 96-hour halt began on September 1. After reviewing Serbian proposals to ensure a peace, the SACEUR, General George Joulwan, dubbed it "snatching defeat from the jaws of victory." After several days of counter-proposals and Serb intransigence, Deliberate Force resumed at midday, September 5. A whirlwind of attacks against air defenses, command and control, storage depots, ammunition dumps, and communications lines followed over the next week-and-a-half. General Ratko Mladic, the Bosnian Serb commander, sued for peace as follow-on attacks pulverized his logistic infrastructure, and reduced his ability to command his forces. On September 14, NATO authorized a 72 hour bombing halt. It extended this for another 72 hours on September 17, by which time it was evident the Serbs were, in fact, removing their weapons. On September 20, NATO and the UN agreed that Deliberate Force was history.

As a result of NATO's first sustained air campaign, all military and political objectives were attained: safe areas were no longer under attack or threatened, heavy weapons had been removed from designated areas, Sarajevo's airport opened (as did road access to the city), and a path to a peace agreement had been secured. It also offered a cautionary tale for peacekeeping operations. Prior to Deliberate Force, the United Nations had struggled with no great success to bring about a peace for nearly four years-- 
and the UN ground presence had suffered a total of 1,690 casualties with 214 killed, of which 708 casualties and 80 killed were as a direct result of enemy action. Operation Deliberate Force established the very conditions the UN had sought to achieve, and did so with the loss of a single French aircraft and the imprisoning (and subsequent release) of its two-man crew. The leverage air power gave was enunciated by former Assistant Secretary of State Richard Holbrooke after the conclusion of the campaign and the settlement of the Dayton Peace Accords when he stated "One of the great things that people should have learned from this is that there are times when air power--not backed up by [NATO's] ground troops--can make a difference. That's something that our European allies didn't all agree with, Americans were in doubt on it, [but] it made a difference." 44

Most recently, NATO forces engaged in air combat over the Balkans, this time to help prevent human rights abuses in Kosovo. While it is too early to pronounce a definitive judgment on the role of air power in the Kosovo operation, several lessons do stand out: First, the noted British historian John Keegan, writing in the Daily Telegraph, is correct when he states: "There are certain dates in the history of warfare that mark real turning points. Now there is a new turning point to fix on the calendar: June 3, 1999,when the capitulation of President Milosovic proved that a war can be won by air power alone. . . the air forces have won a triumph, are entitled to every plaudit they will receive and can look forward to enjoying a transformed status in the strategic community, one they have earned by their single-handed efforts. All this can be said without reservation, and should be conceded by the doubters, of whom I was one, with generosity. . . This was a victory through air power."45 
Secondly, the conclusion initially pronounced by the United States Strategic Bombing Survey after World War II that "no nation can long survive the free exploitation of air weapons over its homeland [and that] enemy planes enjoying control of the sky over one's head can be as disastrous to one's country as its occupation by physical invasion. ${ }^{, 46}$ What had made that possible was control of the air: the NATO coalition shot down six aircraft during the most recent Balkans fighting, and though two aircraft were lost to Yugoslavian ground defenses, those defenses were never able to prevent NATO from using its air power advantage to prosecute some truly remarkable precision attack missions against key targets. Under NATO attack, Serbian forces in Kosovo felt increasingly constrained, threatened, and intimidated; as one stated later, "They knew everything about us. There wasn't anything they didn't know. If we lit a cigarette they could see it. God knows what they were dropping on us, all sorts of bombs. We didn't expect that intensity. We couldn't fight planes with mortars. And our antiaircraft guys couldn't do anything." ${ }^{47}$ Back in Belgrade, Milosovic faced an increasingly vocal opposition, as well s daily evidence of how strategic aerospace power was successfully destroying his military infrastructure and gradually reducing his nation to a pre-industrial level despite his fighter, missile, and gun defenses. With no real option left, Milosovic was forced to withdraw his military and paramilitary forces from Kosovo, effectively bringing a literal reign of terror to an end, allowing for the return of refugees, and enabling the insertion of NATO and other forces to stabilize the peace, and begin a rebuilding process. 
IV.

\section{$\underline{\text { How Control of the Air Can Be--and Sometimes Has Been--Lost }}$}

Like freedom itself, control of the air is not a permanent quality. It has to be constantly fought for, constantly ensured. It can be lost by poor decision-making thousands of miles away from the scene of a conflict just as surely as it can be lost by an ill-trained pilot in the cockpit of an otherwise superb fighter. It can likewise be lost years before a conflict when military services and national security establishments fail to appreciate the changing nature of air warfare. This happened to many of the European nations before the Second World War, nearly happened to the United States before Vietnam, and Israel risked it in the years between 1967 and 1973. Further, the nature and magnitude of counter-air operations have themselves changed significantly since the days of the great aces. It is profitable to explore how control of the air has traditionally been risked and sometimes lost, has changed in the present day, and what the implications are of this for the development of future fighters and the struggle to control the sky.

\section{Questionable National Strategy and Rules of Engagement}

The overall goals of a nation's leadership, its national strategy, and the rules of engagement followed in pursuing a military course of action obviously can have a profound impact on the success of any military campaign or endeavor. Those governing air operations in Vietnam during the period of the "Rolling Thunder" air campaign of the 1960's were so restrictive, contradictory, and at odds with all common-sense of how to conduct a successful air campaign that the wonder is why America did not lose even more aircraft and aircrews than it did. They signaled the inability of the national political and 
senior military leadership of the United States (particularly during the bitter years of the 1960 's) to produce more than a muddle of confusing signals, intentions, actions, and impulses. In 1964, George W. Ball, the Undersecretary of State, tellingly wrote "We are considering air action against [North Vietnam] as the means to a limited objectiveimprovement of our bargaining position with the North Vietnamese." 48 The "air action" that followed—the on-again off-again air campaign known as Rolling Thunder-has become a notorious example of how not to conduct an air campaign. Air strikes were planned, and rules of engagement established, at White House luncheons every Tuesday. The rules often had an Alice-in-Wonderland quality to them, as when, in the words of historian Mark Clodfelter, "pilots learned that they had authority to strike moving targets such as convoys and troops, but could not attack highways, railroads, or bridges with no moving traffic on them." ${ }^{49}$ Such decision-making, when coupled with training, tactics, and equipment shortfalls, and a tenacious and resilient foe, generated high loss rates and low rates of military effectiveness, discrediting air power as a significant and decisive form of power projection.

\section{Poor Doctrine and Tactics}

Obviously, following the wrong doctrine and using the wrong tactics can critically limit the effectiveness of otherwise good forces. During the Battle of Britain, German fighters were tied so closely to German bombers, in the mistaken belief that such close escort would prevent RAF fighters from attacking the bombers, that the exact opposite result was achieved: the maneuver and freedom of the fighters was so constrained that they could not seek out and destroy their British enemy, and the bombers, lulled into a false confidence, were easy prey for marauding Hurricanes and Spitfires. for its part, 
RAF Fighter Command relied on prewar-developed tight "vic" formations of three aircraft to undertake rigid and highly stylized attacks from the stern against enemy bombers. While theoretically these worked well, under actual combat conditions they limited many other potential attack methods--such as diving and head-on passes--and, worse, caused numerous losses of wingmen who, literally, never knew they were being attacked from astern until they were shot down. As a result, the more fluid and useful "finger four" made up of two teams of leader and wingman prevailed for the rest of the war, until replaced in the jet era with more appropriate formations such as the "loose deuce."

Ironically, when the United States took its air war against Germany in 1943, the Army Air Forces' P-47 Thunderbolts were tied as closely to lumbering B-17 and B-24 formations as the Luftwaffe's Messerschmitt Bf 109s had been to the various Heinkels, Dorniers, and Junkers during the Battle of Britain, and with equally dismal results. When General James H. "Jimmy" Doolittle took over as commander of the $8^{\text {th }}$ Air Force, he recognized immediately the need to free the fighters from defensive close escort to offensive fighter sweep. Doolittle dramatically signaled his action by directing that a sign in fighter headquarters reading THE FIRST DUTY OF THE EIGHTH AIR FORCE FIGHTERS IS TO BRING THE BOMBERS BACK ALIVE be torn down and replaced by one reading THE FIRST DUTY OF THE EIGHTH AIR FORCE FIGHTERS IS TO DESTROY GERMAN FIGHTERS. "Your first priority," Doolittle told the commander of the $8^{\text {th }}$ s fighter forces, "is to take the offensive." ${ }^{50}$ With this change in direction, the stage was set for the destruction of the Luftwaffe's fighter force that led to the air supremacy the Allies enjoyed at Normandy six months later. 


\section{Weak Training}

Weak training is a literal "killer" to effective air operations. During the Second World War, the loss of highly skilled prewar aircrew cadres severely hampered both the Luftwaffe and the Japanese army and naval air services. While small numbers of expert fighter pilots remained, air combat had taken a huge toll of experienced fliers, and the training establishments could not keep up with combat losses. In particular, from 1944 onwards, novice German and Japanese pilots were being sent to operational units with flight time measured in the dozens, rather than hundreds, of hours, and they quickly fell prey to more highly skilled--and combat experienced--Allied pilots. In Korea, American Sabre pilots generally possessed better flying skills and backgrounds than their MiG opponents. Some Communist airmen mishandled their aircraft so badly during dogfights that the sight of an out-of-control MiG spinning earthwards through no fault but that of its pilot was not an uncommon occurrence. After the destruction of the Berlin Wall and the reunification of the "two Germanys," Luftwaffe fighter pilots were surprised how their East German opposite numbers failed to take advantage of the impressive performance of the MiG-29, thanks to training that demanded unbending conformity to Soviet-style ground-controller-dominated tactics. (In fact, in dissimilar training sorties, average West German F-4 crews easily engaged, outmaneuvered, and defeated "experienced" East German MiG-29 pilots--something that should have been extremely difficult at best). Clearly, during the Gulf War, Iraqi airmen and air defenders showed the weaknesses of the rigid "by the book" centralized air defense training they had received from Soviet instructors. 
But the United States has not been immune from its own training failures, as the Vietnam War dramatically showed. In the run-up to that conflict, again reflecting the mistaken idea that the era of classical dogfighting was over, fighter squadrons did not hold regular (or even any) air combat maneuvering training against other aircraft, or routinely shoot at towed targets or take missile shots at drones. Many pilots had never shot aerial gunnery practice, and, when taken under actual fire, had little idea how best to exploit their aircraft. One fighter pilot recalled a training sortie where he closed behind four F-4 Phantoms: "The sight that remains in my mind from this experience is a chilling one, for any number of MiG pilots must have seen identical views: the pitiful spectacle of four super aircraft in front of you, all tucked in close finger-four, pulling a level turn. An Atoll [Soviet heat-seeking missile] fired anywhere in parameters would find itself in the position of the proverbial mosquito in the nudist colony. It would hardly know where to begin." ${ }^{51}$ In the real world of Vietnam air combat, such was fatal. Losses led to detailed investigations, and out of this came more realistic training, beginning with the Navy's “Top Gun” training program and continuing with the USAF's eminently successful "Red Flag" experience after the war.

What Fighter is Right? Avoiding Unsuitable or Deficient Equipment

Developing the right fighters to begin with has never been easy. Peacetime assumptions are often shattered by wartime experience, and the process of developing fighters has traditionally taken longer and longer--so that, today, quite literally, there is no opportunity to catch up or make up for mistakes made at the outset of fighter acquisition and defense planning strategies. Unsuitable or deficient equipment--principally poor fighter design--has been a traditional reason why control of the air has been risked or lost. 
A truly successful air supremacy fighter must possess balanced qualities and be able to win both the close-in and distant fight. Fighters fail from three basic reasons, primarily when their designers and design teams:

a) fail to understand the mission requirements ("the problem")

b) fail to keep up with rapidly evolving technology, or

c) do not give them the capabilities that they require.

Failure to comprehend the nature of the air combat problem has been typified by the development of "fighters" that either were found wanting in the crucible of combat, or which were recognized after their development as being unsuited for the true nature of air supremacy warfare. These typically involved four kinds of unsatisfactory aircraft: "platform" or "standoff" fighters, "heavy" fighters, "simple" fighters, and "illusory" fighters.

Before the Second World War, some companies imagined an upcoming era of large multi-seat single or multiengine aircraft that would cruise along in relatively benign flight, either escorting friendly bombers or attacking enemy ones, with gunners taking shots at any enemy aircraft that flew within range. The result were big, complex airplanes such as the experimental Bell FM-1 Airacuda, which proved so unsuitable that no future development was undertaken. But in some cases, such aircraft did see service, notably in the case of the British Boulton-Paul Defiant and the American Boeing YB-40. Both were utter failures. Defiants were massacred by Messerschmitts as they attempted to attack bombers during the Battle of Britain, and thereafter were relegated to night-fighting and air-sea rescue work. The YB-40, an attempt to give Flying Fortress formations extra gunfire protection by taking a B-17 and equipping it with extra guns and gun turrets, 
armor, and ammunition, resulted in an aircraft (optimistically called a "destroyer escort") that was itself too heavy and slow to keep up with bomber formations once they had dropped their bomb-loads (and, hence, was now vulnerable itself to being shot down). After several disappointing missions, including the loss of one airplane, the YB-40 was withdrawn from service. Interestingly, this concept of the "standoff" fighter cruising along and lobbing shells at a foe was resurrected in the missile age in the form of the Douglas F6D Missileer program of the late 1950's. Fortunately, it, too, was abandoned before development. While such an approach may be suitable for a very long range antiair capability using extremely long-range air-to-air missiles, the realities of combat indicate that a fighter has to have more balanced qualities, including the ability to survive contact with the enemy--the close-in, hard-maneuvering "knife-fight." And in this regard, all such "platform" aircraft were--and are--deficient.

"Heavy" fighters were a variation on this theme: typically twin-engine aircraft having the same size as a light bomber, and intended to engage enemy bombers by day. But when war actually came, these aircraft (typified by the Messerschmitt Bf 110, optimistically called a Zerstörer: "Destroyer", and the British Bristol Blenheim--which had, in fact, started life as a light bomber) needed their own fighter escort just to survive. Messerschmitt Bf 110's were shot out of the sky like so many ducks during the Battle of Britain, and thereafter relegated largely to night fighter duties, which they performed reasonably well. Blenheims, whether bombers or fighters, proved incapable of surviving day combat against enemy fighters and were likewise used at night. Even more suitable and powerful fighters, such as the Bristol Beaufighter, De Havilland Mosquito, and even 
the American Lockheed P-38 Lightning, were handicapped when fighting against lighter, more nimble, and faster opponents.

The other extreme, which might be termed "simple fighters" was equally unsatisfactory. Many of these were inspired by the small and powerful air racers of the 1930's, and had a powerful emotional appeal. But few survived rigorous analysis or went further than flight testing. If they retained their small size (for example, the Bell XP-77), their range, payload, and weaponry tended to be unsatisfactory. If enlarged, they soon resembled more conventional aircraft in size and performance, and thus lost their appeal and reason for existence (for example, the Hughes H-1 racer was briefly considered for fighter development in the mid-1930's, but, when military equipment was added to the basic design, it offered no advantages over the existing Seversky P-35 and Curtiss P-36). When some actually entered combat, they proved incapable of either inflicting much damage upon an opponent, or taking much themselves.

Though larger than some of these diminutive aircraft, Japanese fighters of the Second World War offer good examples of the weaknesses of the overly simple approach. At the war's outset, the two leading Japanese fighters, the Mitsubishi Zero and the Nakajima Oscar (the former a Navy and the latter an Army design), both had extremely light structures, good speed, and were extraordinarily nimble. But this came at the price of a powerful armament and any real protection features that could have enabled them to survive combat damage. By the middle of the war, both the Mitsubishi and Nakajima design teams had abandoned this approach in favor of a more Western-style design; the Nakajima Frank and Mitsubishi Jack of the late war period are altogether much more powerful and capable aircraft. 
As with the "platform" or "standoff" fighters discussed earlier, the overly simple fighter has remained a mainstay of defense reform thinking. The F-16 began as a result of this "lightweight fighter" mindset, but the needs of the Air Force and NATO nations eventually dictated that it have more balanced and complete capabilities, as evidenced by current production models of the Fighting Falcon. But even the F-16 was not light or simple enough for some reformers, who called at the end of the 1970's for a series of lightweight single-seat, single-engine, single-weapon hotrods called the "Blitzfighter." Wisely, all services recognized that these concepts were neither militarily useful nor necessarily survivable in combat, and all were rejected.

A final category of unsatisfactory fighter aircraft might be termed "illusory fighters:" aircraft that really are not fighters at all, but are something else. In times of defense contraction, it is understandable that some promote multipurpose aircraft that can seemingly "do anything." This false economy has produced some truly appalling attempts to blend mission requirements, such as: multiseat "reconnaissance" or "spotter" fighters for the Royal Navy that were largely incapable of surviving air combat with faster, more agile, and more numerous German, Italian, and Japanese opponents; French multipurpose (and multiseat/multiengine) "fighters" that had the same problem; and the woeful Tactical Fighter Experimental program of Robert McNamara that led to the F-111, which cost the Navy ten years in fighter design, and which only became a useful Air Force strike airplane after an extraordinary amount of time, effort, and money had been expended. Likewise falling into this category are aircraft that are called fighters, but are really something else: for example, the specialized interceptors of the 1950's such as the Northrop F-89 Scorpion, Lockheed F-94C Starfire, and Convair F-102/F-106. While 
excellent as bomber interceptors, none of these could have successfully contested by day with opposing enemy fighters of the MiG-17/19/21 families. The F-105 Thunderchief is another example. Although ostensibly a fighter, it was, in reality, a nuclear strike aircraft that was modified as a conventional attack bomber. While it could under favorable circumstances shoot down enemy fighters foolish enough to place themselves at risk, its air-to-air victory : loss ratio in Southeast Asia was only $1.30: 1$.

Fighters have also suffered because they stayed in service too long (as the pace of aeronautical development progressed), failed to incorporate appropriate new technology (whether because of design failure, or because economic circumstances would not permit building in such potentially force-multiplying capabilities), or lacked key equipment that could have enhanced their performance. For example, at the beginning of the 1930's, for a brief period, American commercial air transports, typified by the Boeing 247 and the Douglas DC-2, were actually outrunning operational in-service American fighters-because the transports (driven by economic desires promoting speed and efficiency) were high-speed streamlined all-metal monoplanes, and the fighters (thanks to reduced defense spending triggered by the Depression) were rapidly obsolescing open-cockpit, fabriccovered, strut-and-wire-braced high-drag biplanes. (Doctrine also played a role, as many fighter pilots both in America and abroad favored the high agility of the biplane over the higher speed of the monoplane, failing to appreciate how speed would enhance their ability to control enemy airspace). In foreign service, this led to British and Italian fighter biplanes flying in combat long after they should have been relegated to training establishments and museums. The pace of technological change likewise has led to some "paradigm shift" encounters since that time: for example, as was mentioned earlier, the 
confrontation between German jet fighters and Allied piston-engine fighters in 1944 (and even later, between propeller-driven fighters such as the F-51 and F4U Corsair and the MiG-15 in Korea), the confrontation of subsonic straight-wing and transonic sweptwing jet fighters in Korea, or (from the other perspective) the confrontation of advanced F-15's and earlier generation MiG-21, MiG-23, and Mirage F-1 fighters in the Gulf.

Finally, the absence of key equipment has often seriously limited the effectiveness of a fighter. When American fighters first went to war in Europe in support of Allied bombers operating against the Nazis, they lacked jettisonable fuel tanks--a "lesson lost," for American fighters in the 1930's had carried them, and, overseas, Japanese fighters had used them in combat as early as the Sino-Japanese War. As a result, bombers had to be abandoned to the less-than-tender mercies of the Luftwaffe until this situation was remedied. The Bell P-39 Airacobra has become synonymous with poor performance. In reality, its prototype, equipped with a turbosupercharger, had outstanding performance. But the Army Air Corps was unwilling to produce the P-39 with a turbocharger, apparently fearing that its development would be prolonged. This aircraft, which did much good service at low altitudes, was incapable of successfully engaging enemy aircraft at medium and high altitudes. The same nearly happened to the legendary North American P-51 Mustang. When it first entered service, it used an engine incapable of giving it good high altitude performance. Had the Rolls-Royce Merlin not been adapted to this otherwise outstanding design, the Mustang might have remained an intriguing "what if" rather than arguably the finest propeller-driven air-to-air fighter ever built. And, of course, there is the story of the internal gun on the F-4 Phantom, a continual 
source of irritation to early F-4 pilots who wished they had possessed the internal gun when they “went North" against MiG-17's and MiG-21's in the mid-1960's.

\section{Confronting The Integrated Fighter-SAM Air Defense Network Threat}

Since Vietnam onwards, the presence of modern fighters and modern missile systems, operated by professionally capable forces and as part of a total integrated air defense system, has transformed what, in the pre-missile era, was largely a straightforward confrontation between opposing airplanes. In World War II and Korea, the issue of protecting strike aircraft (bombers) was typically a matter of arranging for fighter sweeps ahead of bomber formations. While not innocuous, the ratio of support aircraft (fighters) to strikers (bombers) was still relatively low; for example, one raid into Germany in the summer of 1944 involved 1,129 B-17 and B-24 bombers protected by 756 P-38, P-47, and P-51 fighters, a ratio of 0.67 : 1--that is, 0.67 fighters for every bomber. After the introduction of surface-to-air missiles, strike aircraft required protection from both fighters and missiles, and this drove a tremendous increase in the ratio of support aircraft to strike aircraft. For example, in 1972, a typical American strike package into North Vietnam consisted of fifty-eight airplanes: sixteen bombers (the strikers, just $28 \%$ of the force), twenty-two air superiority fighters (to shoot down MiG's), eight chaff dispensers (to jam radars), eight Wild Weasels (to hunt and destroy SAMs), two electronic jammers (for other electronic warfare), and two post-strike reconnaissance aircraft for bomb damage assessment: altogether a ratio of nearly three support airplanes for every strike airplane.

By the time of the Gulf War and the Balkans, support aircraft-to-strike aircraft ratios had risen even higher. For example, on opening night of the war, a force of 38 
airplanes attacked Tallil airfield, striking at three aimpoints. This force consisted of eight attack aircraft (four Navy A-6E Intruders and four Saudi Tornadoes), screened by four F4G Wild Weasels, five EA-6B Prowler jammers, four F/A-18C Hornets flying MiGCAP, and no less than 17 F/A-18C Hornets carrying radar-homing missiles: a support-to-strike ratio of nearly $4: 1$. Balkan air operations continued this trend, particularly after the shootdown of Scott O'Grady. The first day of the Operation Deliberate Force strikes in 1995 involved a total of 129 aircraft attacking Serb air defenses, the necessary prelude for follow-on air activity, what one historian, Christopher Bowie, has termed "100\% virtual attrition of the attacking force" since every sortie was "lost" to protection from enemy air defenses, rather than striking at Serbian offensive military capabilities. ${ }^{52}$

Subsequently, after Operation Allied Force in 1999, General John Jumper, the commander of U.S. Air Forces in Europe, stated that his greatest fear, and that of the theater commander, General Wesley Clark, was "that somehow Mr. Milosovic would find a way to float an SA-10 or SA-12 up the Danube River, put it together and bring it to bear as a part of this conflict. If that had happened it would have profoundly changed the balance of the threat and our ability to maintain air superiority. Likewise, the existence of modern generations of fighters--Su-35s and their equivalents that are available today-would have had a profound impact on the balance that was so heavily tilted in our favor., ${ }^{\text {,3 }}$ Fortunately, such did not occur, and, instead, as Jumper noted, "Their SAM operators were, in the end [of the conflict], afraid to bring the SAMs up and engage our fighters because of the lethality of our anti-SAM aircraft." ${ }^{54}$ The director of Combat Weapon Systems for the Air Force's Air Combat Command, Major General Dennis G. Haines, reflected on implications of the Kosovo experience for future operations by 
noting "We must be prepared to counter a much improved integrated air defense system., $" 55$

The threat posed by modern integrated air defense systems, many of which feature increasingly longer-range air defense systems such as the Russian S-300 family of missiles, coupled with innovative approaches such as passive electro-optical tracking of targets, offers a particular challenge to operating over, gaining, and controlling enemy airspace. One clear message is the value of stealth. For example, during the Gulf War, at the same time as the Tallil strike discussed above (which had 8 strike aircraft hitting just 3 aimpoints screened by 30 aircraft), 20 F-117 stealth fighters were attacking 37 even more heavily defended aimpoints, and without any supporting aircraft at all. For the future, the combination of stealth and speed promises to dramatically reduce an enemy's ability to react to an attacker, and achieve a synergistic benefit for the attacker that is more powerful than either stealth or speed on its own. The potential of the high-speed stealthy attacker may be further enhanced by traditional airborne jamming, but is not dependent upon it as are conventional non-stealthy "legacy" attack aircraft. Stealth is critical, for the demands for support aircraft to enable such conventional strikers to survive in a heavily defended block of airspace are so great that, in the post-Cold War era, procuring the necessary number of support aircraft to do the job (in the absence of stealthy attackers) would call into serious question both the ability of the United States to afford them, and the willingness of decision-makers to then risk them in various crisis situations. 


\section{Implications for the Future of American Air Supremacy}

Obviously, then, the "bottom line" must always be that a fighter first and foremost has to possess the ability to engage an opponent in both the long-range and close fight, via balanced qualities of speed, agility, sensor capability, weapons--and now, at the turn of the century, stealth-- to fight a wide range of potential enemies. This was, for the most part, why the so-called "superfighters" of the 1970's proved so successful in military service. With some differences, these nevertheless generally exploited the higher thrustto-weight capabilities of modern turbojet engine technology, the ability to exploit tailored aerodynamics for better agility and safety, and the maneuver-enhancing advantages of highly stability-augmented flight control systems, or digital fly-by-wire flight controls. The result, since Vietnam, has been an unprecedented era of American air supremacy; for example, no F-15 or F-16 aircraft, flown by American or allied nations, has ever been shot down in air-to-air combat, but these two aircraft types have, between them, shot down over 130 opponents ranging from MiG-21's to MiG-29's and Mirage F-1's.

But given the tremendous proliferation of surface-to-air missile systems, networked air defense systems, and newer generation fighters such as the emerging advanced Sukhoi Flanker family, it is impossible to guarantee that this level of air supremacy--indeed dominance--will continue, unless the right choices are made in fighter acquisition. Confronting opponents with near-parity capabilities in regional interventions may well involve risking the loss of aircraft, ships, surface warfare systems, and far, worse, the lives of American and friendly forces, in order to achieve our national ends. 
With the large-scale drawdown that has affected all American military forces since the end of the Cold War, coupled with the ironic increase in need for American presence and power projection, any losses may well prove nearly--or perhaps even--intolerable, for the number of forces able to be projected quickly into a crisis region may be small, and thus vulnerable to an enemy's attrition strategy. In short, the model of Israel in 1973 and Britain in the Falklands should ever be kept in mind.

Given America's aging fighter force--all the current designs in service date to the late 1960's and early 1970's--what is required is a dominant fighter. But a cursory review of existing in-service fighter aircraft across the air forces of the world indicates that, by and large, the traditional fighter qualities are "not enough." Essentially, looking at all potential threat nations, and many nations in unstable regions of the world, reveals that virtually all:

a. Have supersonic dash speed to $\mathrm{M}=1.5+$;

b. Have high altitude $(50,000 \mathrm{ft} .+)$ interception capability;

c. Have thrust-to-weight ratios greater than 1 ;

d. Have near or actual $9 \mathrm{~g}$ maneuvering for positional advantage ;

e. Have short-range IR and medium range radar missile capability;

f. Have some degree of integrated air defense systems (IADS) of varying capabilities, with layered AAA, SAMs, and fighters.

What are, then, the true hallmarks of a dominant fighter in the present day? What are the qualities that separate a fighter from "the pack?" The following, in the absence of others possessing them, war-winning and revolutionary qualities:

a. The ability to evade and/or minimize detection (stealth) 
b. The ability to transit threat areas quickly (supercruise)

c. The ability to exploit information warfare (sensor fusion)

This alone is a powerful argument for the only contemporary American fighter program to possess both traditional and revolutionary qualities, the F-22 Raptor. Blending these qualities, the Raptor has the ability to win the battle for control of the air by exploiting its qualities to ensure first look, first short, and first kill against any air opponent. It can turn to the surface and use its qualities of stealth and speed to evade threat envelopes of surface-to-air missile systems, and use sophisticated precision weapons to engage surface targets itself, complementing earlier stealth aircraft systems such as the F-117. Indeed, its operations will enhance the effectiveness of America's stealth weapon force--the F-117 and B-2 strategic bomber. With air control secure, all other non-stealthy legacy aircraft can concentrate on their primary mission roles, rather than having to fight for their lives against air and surface air defense threats.

But can American make do without the F-22? The answer is a hard one: If we wish to ensure that we retain the same kind of air supremacy over future opponents that our surface warfare colleagues both expect and have become used to, no other viable options exist. The F-15 and F-16 are already twenty-plus years old and continued multistage improvement programs can at best keep them at an "air parity" or "air superiority" level of competence with existing threat aircraft, and possibly only at an "air inferiority" level with newer and projected threat aircraft such as the advanced Sukhoi Flankers. Other American fighter programs are at best complementary to the F-22, for example, the still-paper Joint Strike Fighter (JSF) and the F/A-18E/F, are at best complementary to the F-22 and clearly are not suitable substitutes for it. The national 
military leadership recognizes this. Every member--every single one--of the Joint Chiefs have come out in support of F-22 procurement, as have all the theater "CINCs", from all services. While critics have accused the Raptor as being too costly, in fact that cost is consistent with the level of technical capability that it promises, and the previous history of fighter aircraft development and evolution. For a buy of 339 aircraft (as opposed to an original program goal of 750), the Raptor has a unit cost of $\$ 84.7$ mission. Under current planning, this drops to about $\$ 65$ million per copy over the life of its production run. Any "cheaper" solution would result in the expenditure of far more dollars on additional support aircraft, training and crew requirements, life cycle costs, and the like. The Raptor, in short, is the cost-effective and mission-effective answer to the challenge of maintaining future American air supremacy--indeed dominance--over our opponents in the $21^{\text {st }}$ Century.

In sum, control of the air enables joint warfare, and ensures joint victory. The lessons of history teach that, now and in the future, gaining air supremacy over potential foes means the F-22, not some "improved" existing fighter, or some mythical "does everything" paper airplane or long-range standoff platform. Failure to procure the F-22 would mark the first time since the Second World War that the United States has consciously chosen to send its soldiers, sailors, and airmen into harm's way while knowingly and willingly conceding the international lead in fighter development to foreign nations who may sell their products on the world arms market to potential enemies. And that would be tragically wrong. 


\section{Source Notes}

${ }^{1}$ Richard B. Frank, Guadalcanal (New York: Penguin Books, 1992), p. 609.

${ }^{2}$ Ibid.

${ }^{3}$ U.S. War Department, Field Manual FM 100-20, Command and Employment of Air Power, 21 July 1943.

${ }^{4}$ E-mail Message, Wayne Thompson, Air Force History Support Office, Bolling AFB, DC, to Brett A. Loyd, SAF/AQPF, Pentagon, Washington, D.C., 24 August 1999.

${ }^{5}$ Herzog, The War of Atonement: October, 1973 (Boston: Little, Brown and Company, 1975), p. 256.

${ }^{6}$ Weinraub, "The Israel Air Force and the Air Land Battle," Israeli Defense Forces Journal, III. n. 3 (Summer 1986), p. 23.

${ }^{7}$ Michael Clapp and Ewen Southby-Tailyour, Amphibious Assault Falklands: The Battle for San Carlos Water (London: Orion, 1996), p. 209.

${ }^{8}$ Royal Navy Directorate of Naval Staff Duties, The Fundamentals of British Maritime Doctrine, BR 1806 (London: HMSO, 1995), p. 68. [Emphasis in original text] Additionally, Annex B, "The Falklands War 1982 from the Viewpoint of Doctrine," (pp. 189-195) is a useful summary of the campaign.

${ }^{9}$ Marshall, Memo to the Secretary of War, May 16, 1944, reprinted in Larry I. Bland, ed., The Papers of George Catlett. Marshall, v. IV, p. 449.

${ }^{10}$ Friedrich Ruge, Rommel in Normandy: Reminiscences by Friedrich Ruge (San Rafael, CA: Presidio Press, 1979), pp. 15. See also 26, 38, 64-66, 143, 152, 159, 167, and 172.

${ }^{11}$ Galland, The First and the Last: The Rise and Fall of the German Fighter Forces, 1938-1945 (New York: Henry Holt and Company, 1954), p. 274.

${ }^{12}$ Zimmermann, "France, 1944," in Seymour Freidin and William Richardson, with Werner Kreipe et. al., The Fatal Decisions (New York: William Sloane Associates, 1956), p. 215.

${ }^{13}$ Galland, pp. 280-281.

${ }^{14}$ John S. D. Eisenhower, Strictly Personal (Garden City, N.Y.: Doubleday, 1974), p. 72.

${ }^{15}$ B. H. Liddell Hart, ed., The Rommel Papers (New York: Harcourt, Brace and Co., 1953), p. 491.

${ }^{16}$ Quoted in John S. D. Eisenhower, The Bitter Woods (New York: G. P. Putnam's Sons, 1969), p. 40.

${ }^{17}$ Zimmermann, "France, 1944," in Freidin et. al., Fatal Decisions, p. 227.

${ }^{18}$ General Dwight D. Eisenhower, Supreme Commander's Despatch for Operations in Northwest Europe, 6 June 1944-8 May 1945 (SHAEF, n.d.), pp. 43-44. Document catalogued as D756 A24c c.2, in the U.S. Army Military History Institute Library.

${ }^{19}$ Maj. Gen. Rudolf-Christoph von Gersdorff, "Northern France: vol. 5 [Fifth Panzer Army (25 Jul-25 Aug 44)]," Manuscript B-726 (Historical Division, HQ U.S. Army, Europe, n.d.), pp. 33-34, and "The ArgentanFalaise Pocket," Manuscript A-919 (Historical Division, HQ U.S. Army, Europe, 1954), pp. 5-6; copies of both are in the U.S. Army Military History Institute Library. 
${ }^{20}$ Dwight D. Eisenhower, Crusade in Europe (Garden City, N.Y.: Doubleday, 1948), p. 279.

${ }^{21}$ Speidel, Invasion 1944: Rommel and the Normandy Campaign (Chicago: Regnery, 1950), p. 170.

${ }^{22}$ General Omar N. Bradley and the Air Effects Committee of the $12^{\text {th }}$ Army Group, Effect of Air Power on Military Operations: Western Europe, a report prepared for the United States Strategic Bombing Survey (Wiesbaden, Germany: HQ $12^{\text {th }}$ Army Group, Air Effects Committee, July 15, 1945), p. 180.

${ }^{23}$ Manteuffel, "The Ardennes," in Freidin et. al., Fatal Decisions, p. 290.

${ }^{24}$ Bradley et. al., Effect of Air Power. . . p. 157.

${ }^{25}$ Ibid., p. 171.

${ }^{26}$ Ibid.

${ }^{27}$ Manteuffel, “The Ardennes,” in Freidin et. al., Fatal Decisions, p. 286.

${ }^{28}$ Bradley et. al., Effect of Air Power. . ., p. 181.

${ }^{29}$ Ibid., p. 184.

${ }^{30}$ Abstract of a symposium paper by Col. Dr. Mordechai Bar-On, "The Israel Air Force in the Six Day War, 1967," presented at the international symposium Conference Air 99: "Military Aviation: A Bird's Eye View of the Century," sponsored by the Service historique de l'armée de l'air, École Militaire, Paris, June 8, 1999, p. 1 .

${ }^{31}$ Ibid., p. 2.

${ }^{32}$ Ibid., p. 3.

${ }^{33}$ Statement of Xuan Vu, quoted in David Chanoff and Doan Van Toai, Portrait of the Enemy (New York: Random House, 1986), p. 185.

${ }^{34}$ Statement of Trinh Duc, in Chanoff and Toai, p. 109.

${ }^{35}$ Statement of Brig. Gen. John R. McGiffert, USA, in John A. Doglione, et. al., Airpower and the 1972 Spring Invasion Monograph 3 of the USAF Air University USAF Southeast Asia Monograph Series, series editor A. J. C. Lavalle (Washington, D.C.: Government Printing Office, 1976), p. 103

${ }^{36}$ Quoted in Lewis Sorley, “Courage and Blood: South Vietnam's Repulse of the 1972 Easter Invasion," Parameters, XXIX, n. 2 (Summer 1999), p. 56, note 26.

${ }^{37}$ Air Vice Marshal R. A. Mason, RAF ret., “The Air War in the Gulf,” Survival, XXXIII, n. 3 (May-June 1991), p. 211.

${ }^{38}$ President George Bush, transcript of remarks at the Graduation of the Class of 1991, U.S. Air Force Academy, Colorado Springs, CO, May 1991.

${ }^{39}$ Tom Clancy with General Chuck Horner, Every Man a Tiger (New York: G. P. Putnam's Sons, 1999), pp. 546-547. 
${ }^{40}$ Thomas A. Keaney and Eliot A. Cohen, GWAPS Summary Report (Washington, D.C.: Government Printing Office, 1993), pp. 56-57.

${ }^{41}$ Clancy and Horner, Every Man a Tiger, pp. 547 ( $1^{\text {st }}$ part), 557-558 (last part).

${ }^{42}$ Keaney and Cohen, GWAPS Summary Report, p. 62.

${ }^{43}$ Quote from Air Force Doctrine Center, "Historical Evidence Database," (Maxwell AFB, AL: AFDC, 1999).

${ }^{44}$ Transcript of statement by Richard Holbrooke to Elizabeth Farnsworth, Newshour with Jim Lehrer, PBS television, Feb. 21, 1996.

${ }^{45}$ Daily Telegraph (London), June 6, 1999.

${ }^{46}$ USSBS, Summary Reports (European and Pacific Theaters) (report, Maxwell AFB, AL: Air University Press, 1987 ed.), p. 110.

${ }^{47}$ Rory Carroll, " 'I'm Not Right in the Head Now:' A Conscript's War," The Observer, London, Sunday 20 June 1999, p. 17.

${ }^{48}$ George W. Ball, "How Valid Are the Assumptions Underlying Our Viet-Nam Policies?" Atlantic Monthly, 230 (Oct. 5, 1964), p. 38. See also memo, Robert S. McNamara to President Lyndon B. Johnson, July 20, 2965, in the Senator Mike Gravel edition of The Pentagon Papers: The Defense Department History of United States Decisionmaking on Vietnam (Boston: Beacon Press, 1975), p. 26.

${ }^{49}$ Mark Clodfelter, The Limits of Air Power: The American Bombing of North Vietnam (New York: The Free Press, 1989), p. 121.

${ }^{50}$ Doolittle with Carroll V. Glines, I Could Never be so Lucky Again: An Autobiography by General James H. "Jimmy” Doolittle (New York: Bantam Books, 1991), p. 380.

${ }^{51}$ John B. Nichols and Barrett Tillman, On Yankee Station (Annapolis, MD: Naval Institute Press, 1987), pp. 85-86.

${ }^{52}$ Christopher J. Bowie, Untying the Bloody Scarf: Casualties, Stealth, and the Revolution in Aerial Combat, a study in the Next American Century Series (Arlington, VA: IRIS Independent Research, 1998), p. 10.

${ }^{53}$ Transcript of statement of Gen. Jumper at the Colloquy "Operation Allied Force: Strategy, Execution, Implications,” The Eaker Institute for Aerospace Concepts, Washington, D.C., August 16, 1999.

${ }^{54}$ Ibid.

${ }^{55}$ Quoted in Robert Wall, "SEAD Concerns Raised in Kosovo," Aviation Week \& Space Technology, v. 151, n. 4 (July 26, 1999), p. 75. 